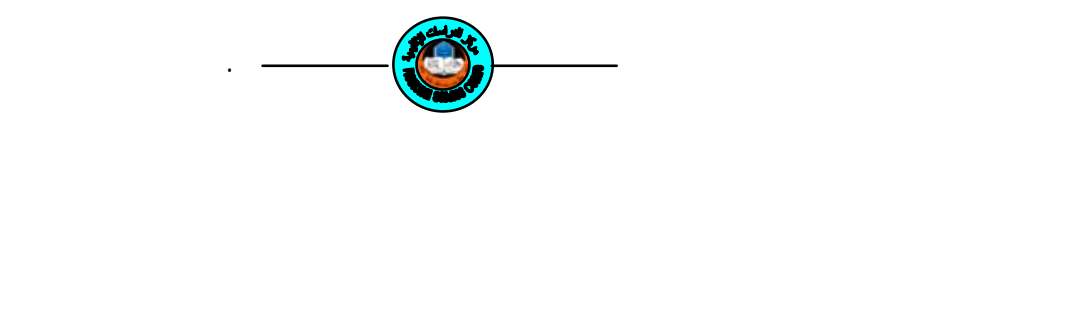

$$
\text { الكتورمعراج عبد الغادر هواري }
$$

نائب عميدمكلف بالبهث العلمي في كلية العلوم الاقتصاية وعلوم التسيير بجلمعة الأغوطا/الجزائر

$$
\text { مستخلص البرث }
$$

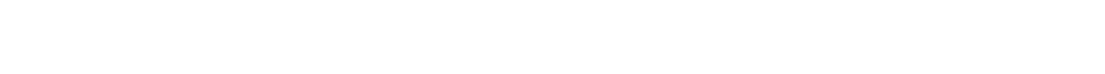

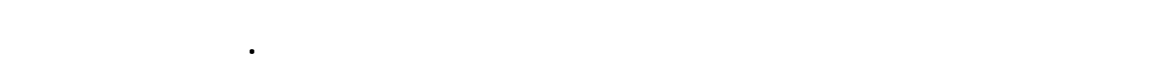

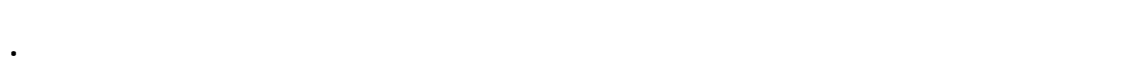

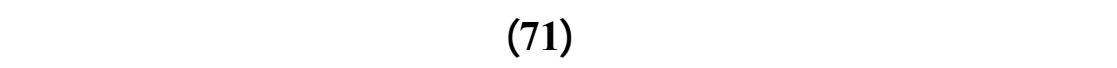

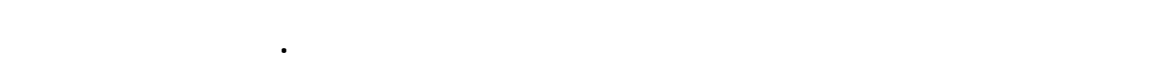

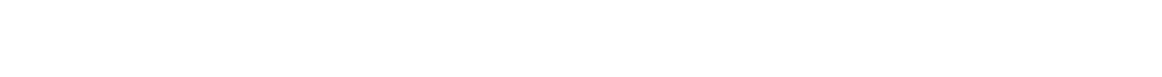

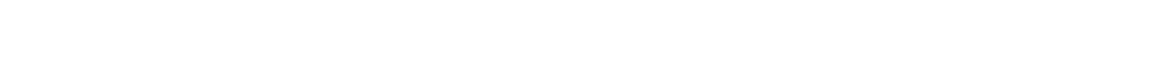

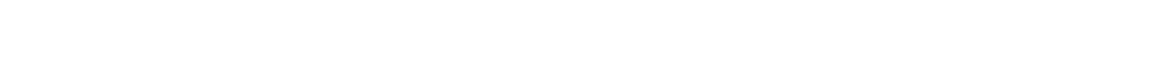

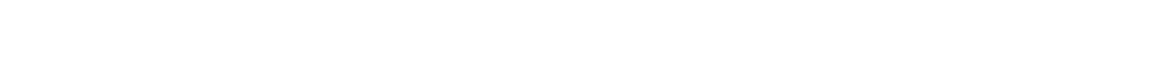
ينعرض لها عضو هيئة التربس.

الكلملت الدالة: هيئة التدريس، الأداء الوظفي، التعليم العالي، تسيير التعليم العالي. 
تسعى مظم الجلمعات ومؤسست التعليم العالي في مختلف الدول

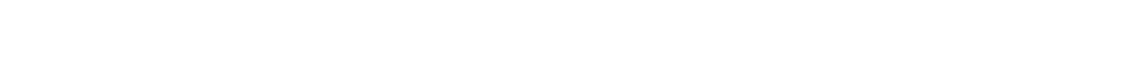

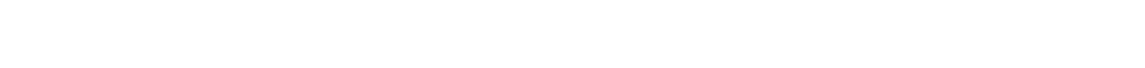

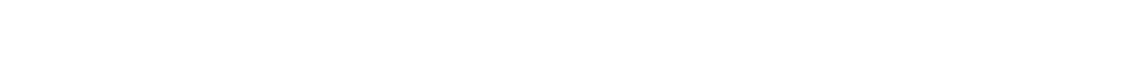
ذالك على مجموعة من الركائز والدعائم لعل أهمها أعضاء هيئ وائة التدريس

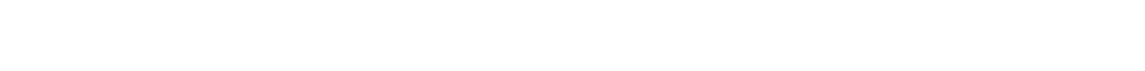
المطلوبة.

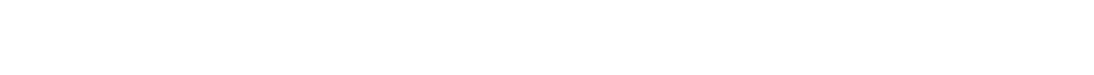

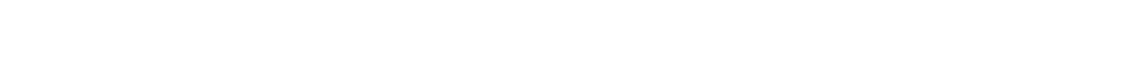

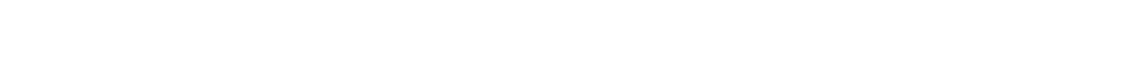

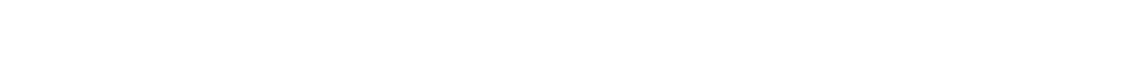

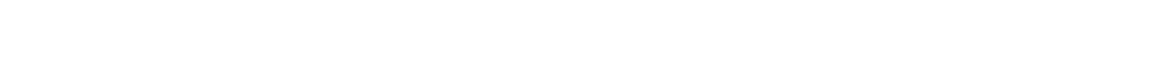

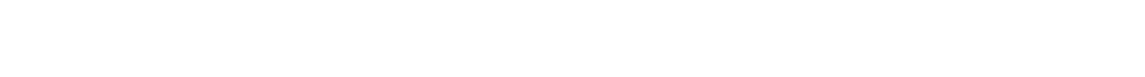

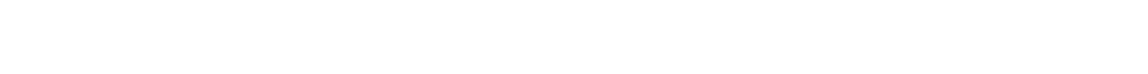
والإحلطة بمجموعة من المقوملت الأسلسية التي تكون له عولية الهونا في القيلم

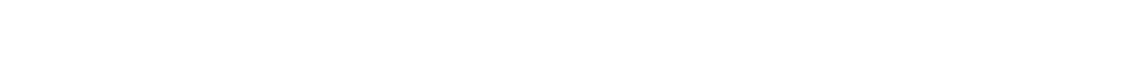
الوظيفي (1)

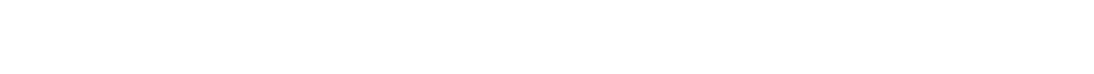

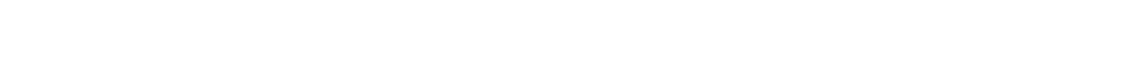

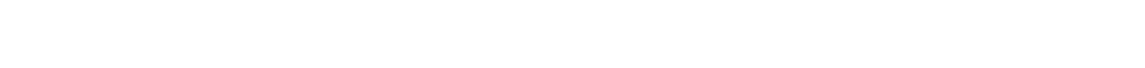

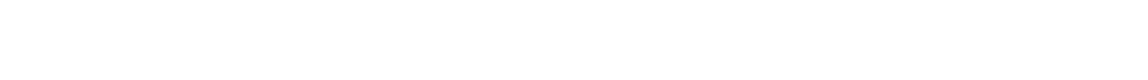

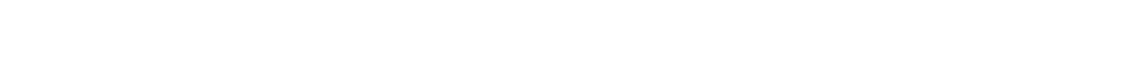




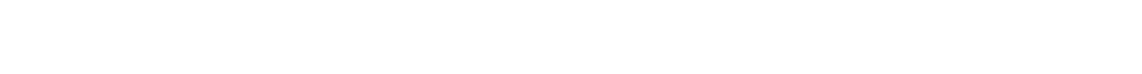

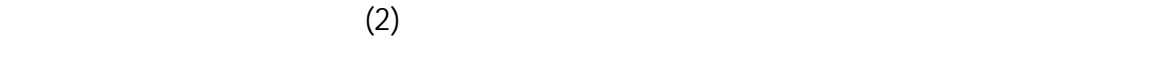

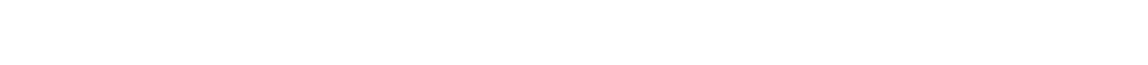

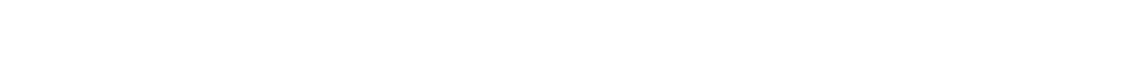

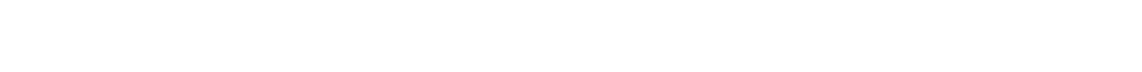

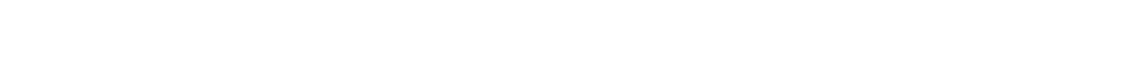

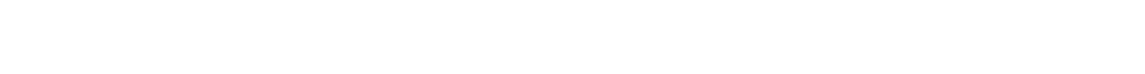

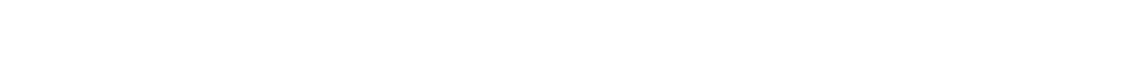

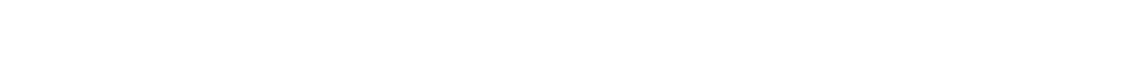
بالكويت واقتراح بعض التوصيت التي ققدم حلولاً لهذه المشلكل.

مثكلة الررالسة: يمكن تحديد مشكلة هذه الدرلسة في التوصل إله معرفة أهم المشلكل التي تولجه عضو هيئة التدريس في كلية العلوم الاقتصاية

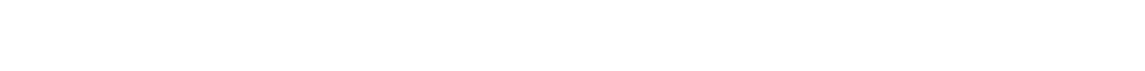
أدائه الوظيفي، وتنبثق من هذه المشكلة الرئيسة عدة تساؤلات هي:

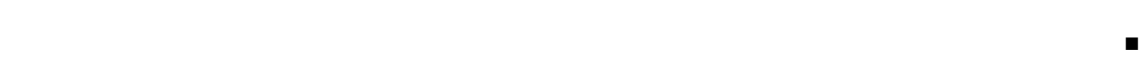

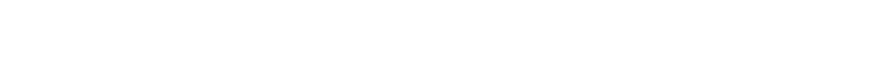
• ما أهم المشلكل الإدارية والمالية التي تولجه عضو هيئة التدريس من التهن

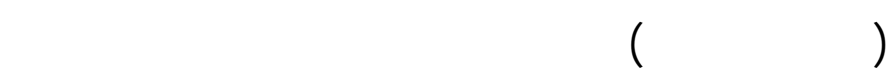

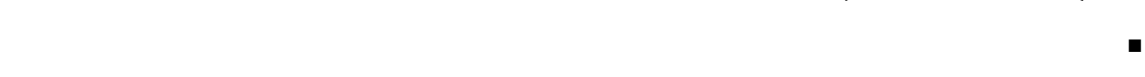

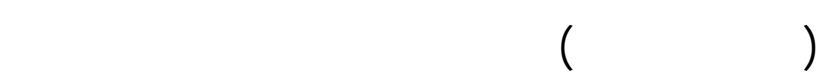

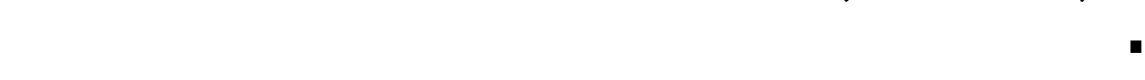
للساقة؟ لُهدل الدرلسة: تهدف هذه الدرلسة إله ما يأتي: • معرفة أهم المشلكل والمعوقلت التي تولجه عضو هيئة الت دريس المه نـ 
(النكور والإنث) بجلمعة الأغوط وتؤثرسلبا عل م مس ـتوى أدائ هـ

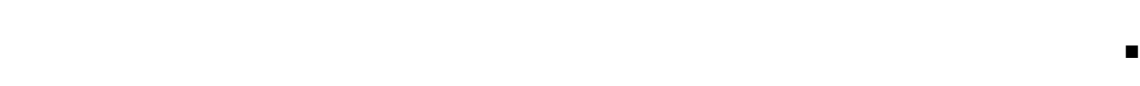

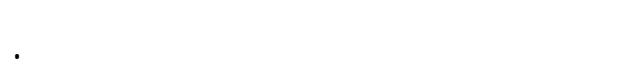

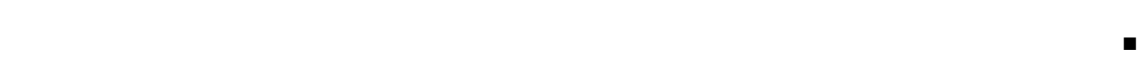
من (الذكور والإنتث) على أدائه الوظيفي.

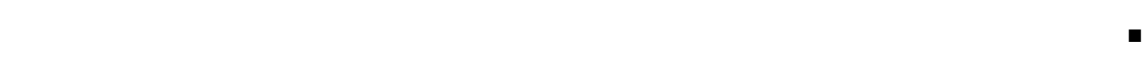
المشلكل التي تولجه أعضاء هيئة التدريس من (النكور والإنث).

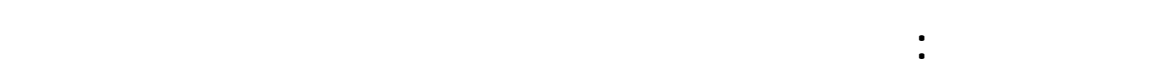

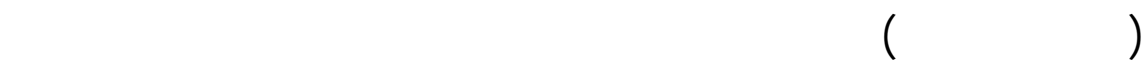
بالكليت والبالغ عددها ثلاث كليلت. لهمية الدرلسة الحالية: تكمن أهمية الدرلسة الحالية فيما يأتي:

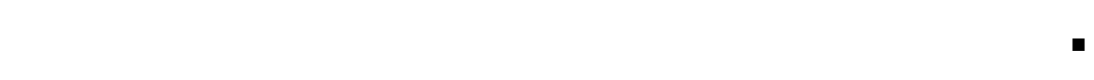

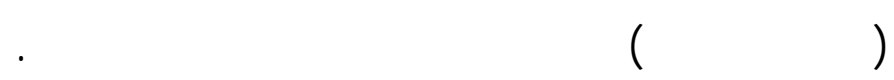

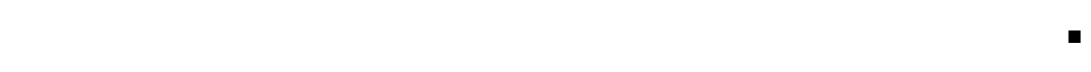

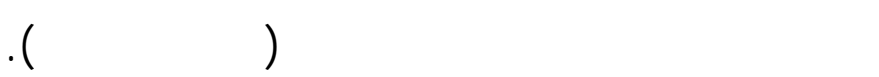

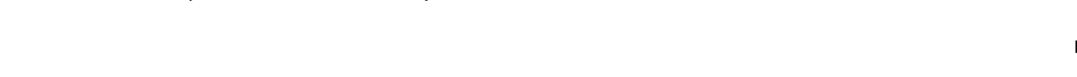

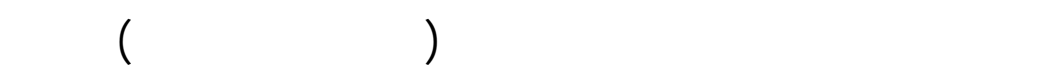
مشلكل ومعوقت تؤثر على مستوى أدائهم الوظيفي. 


\section{الدرلسلت الساقة:}

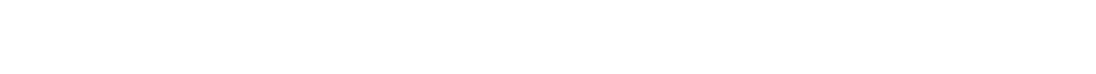

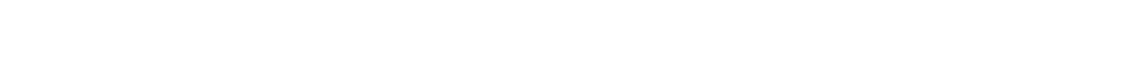

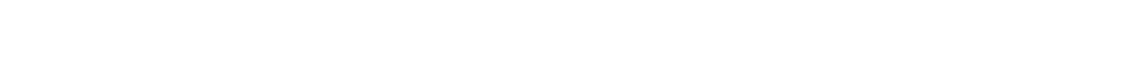
التدريسية والتربوية بوجه علم.

\section{أ) الررلسك العربية:}

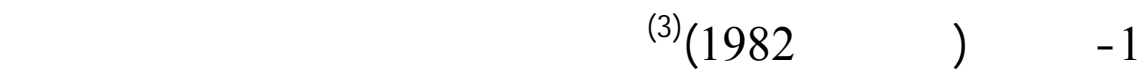

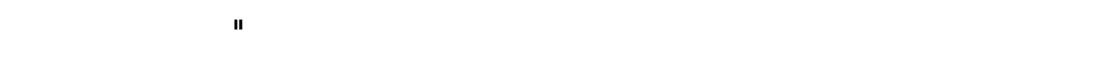

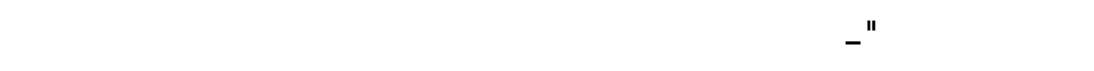

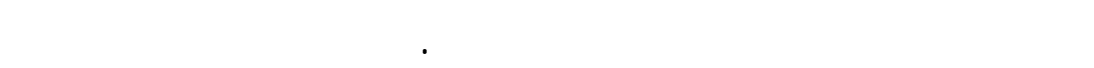

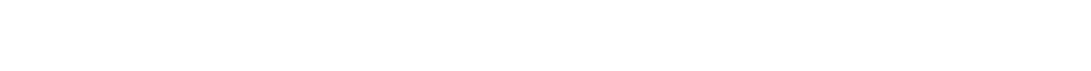

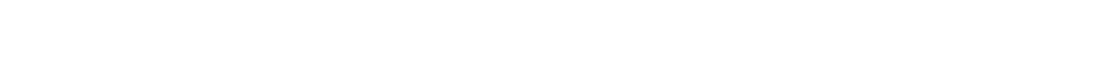

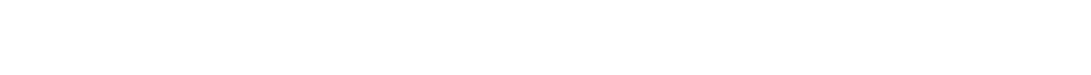

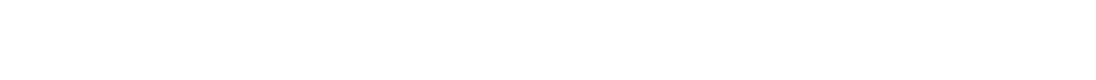
ضغف مستوى فصول الدرلمة والتجهيزات الطلوبة لعملية التدربيس.

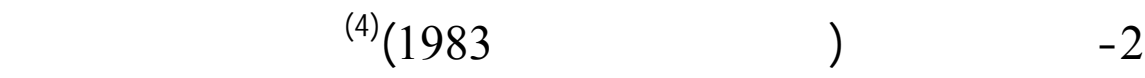

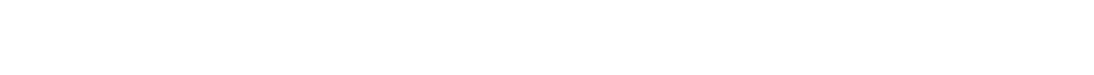

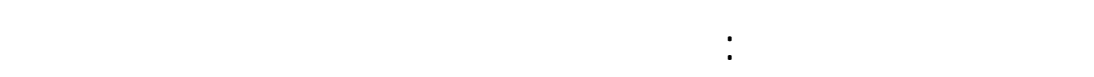

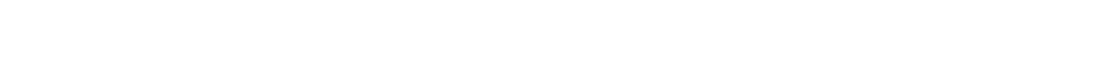

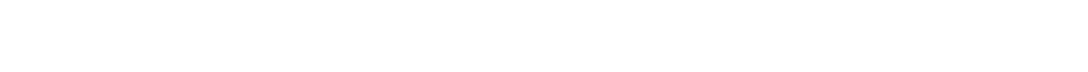

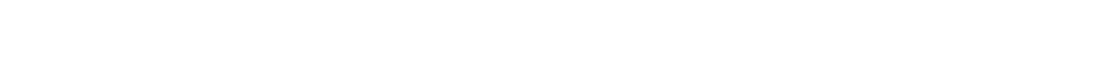

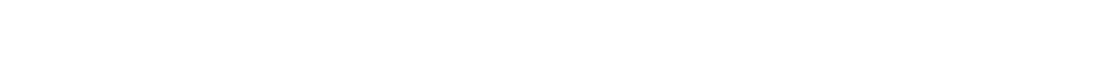




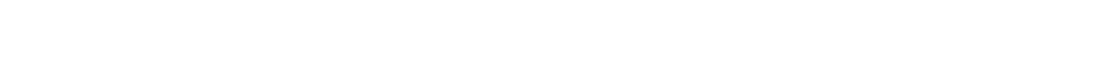
العلمية وأوضاعه الاجتماعية. 3 - ولجرىى (مروان كمل 1983) (5) درلسة حول المشلكل المختلفة التي

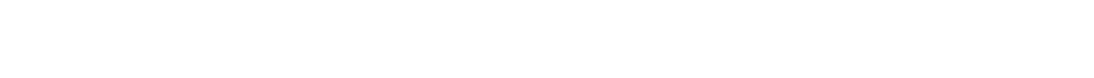

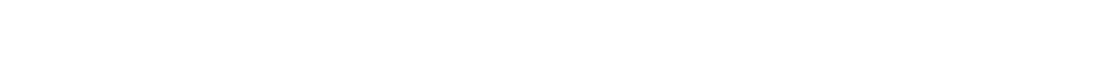

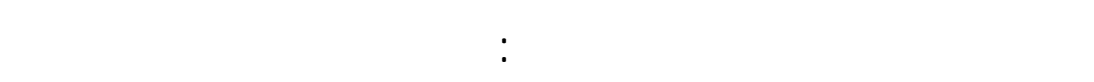

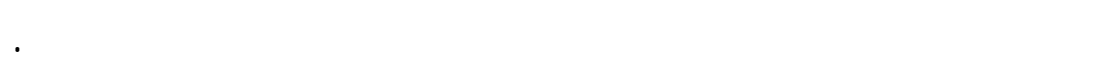

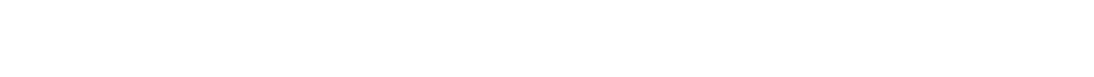

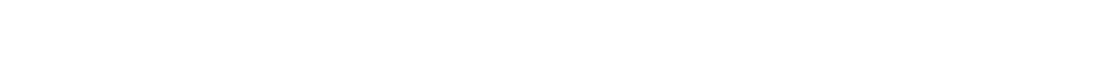

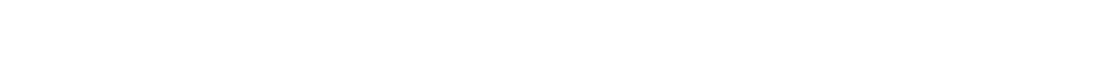

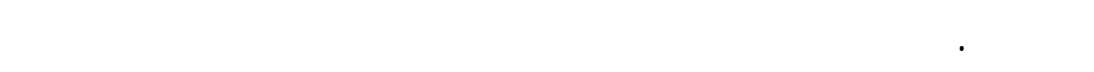

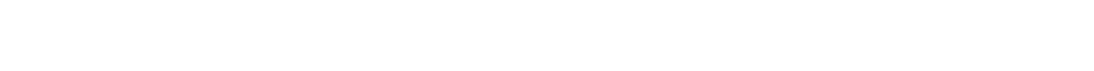

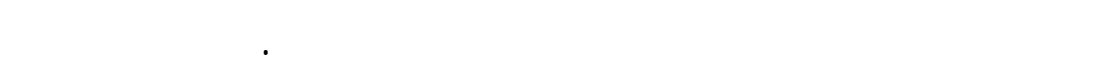

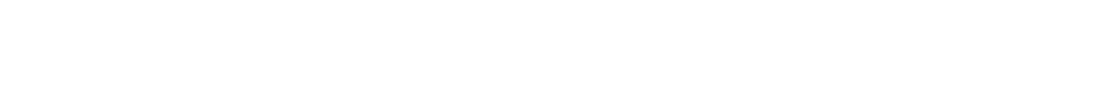

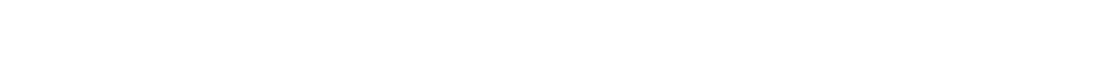

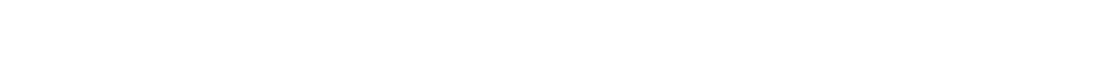

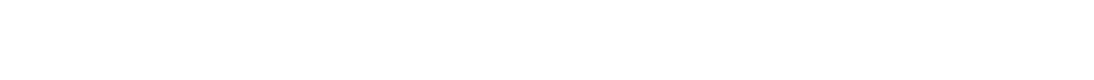

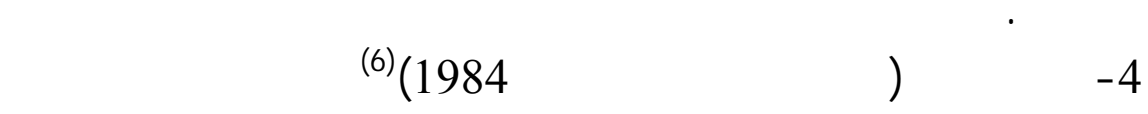

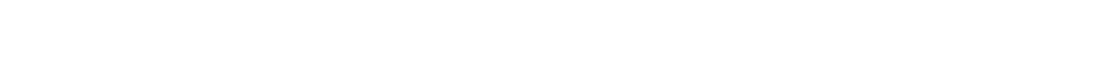

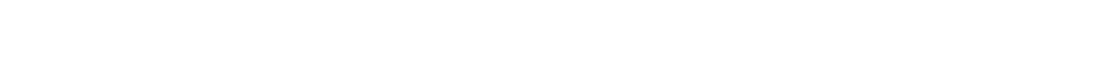

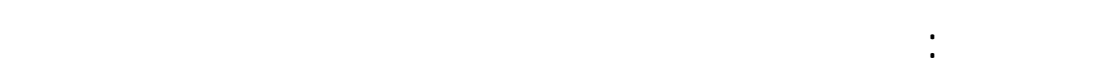

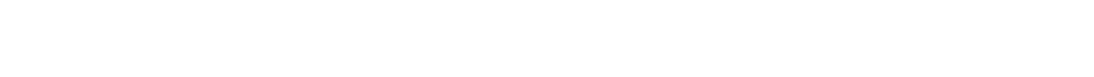


الأمول المخصصة لإجراء البحوث والقص ف مي أع ـداد مس اعدي

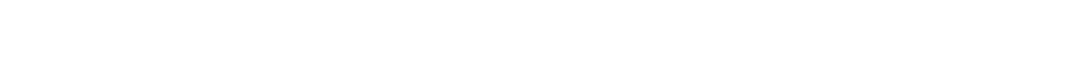

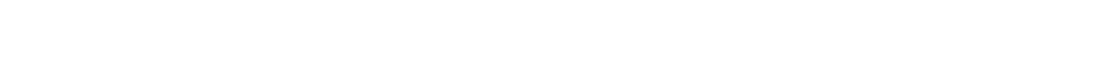

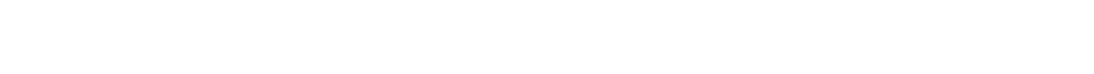

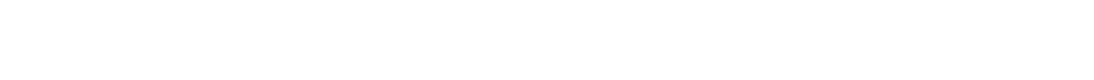

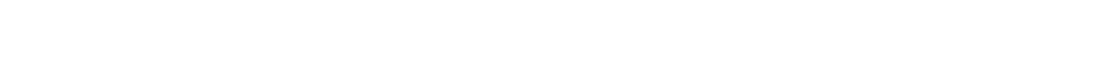

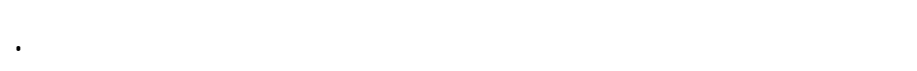

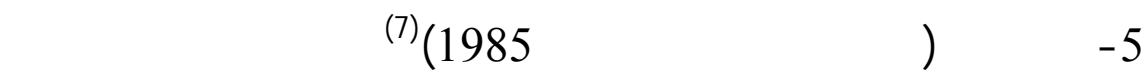

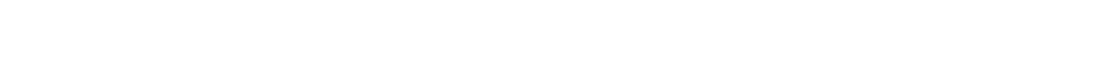

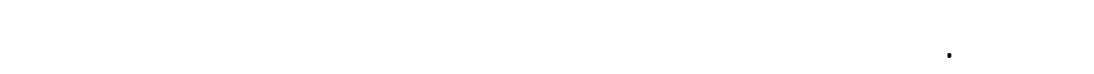

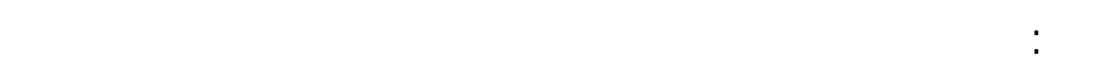

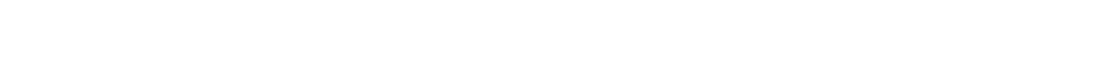

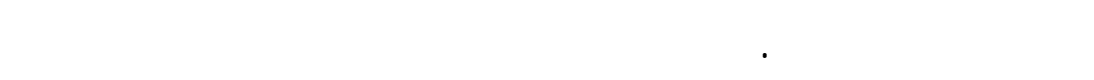

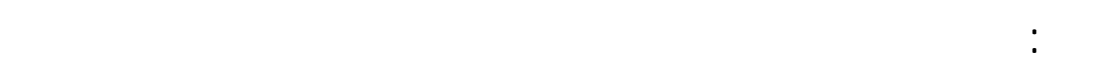

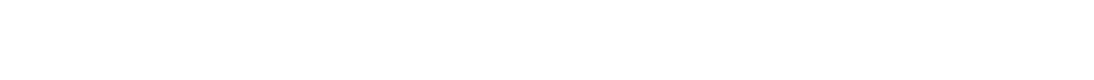

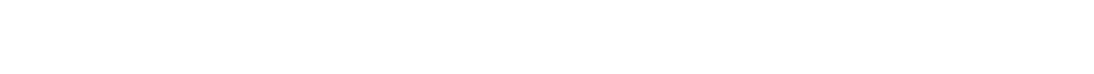

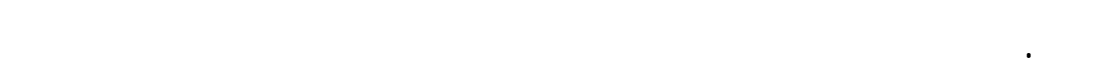

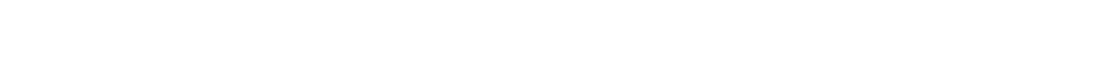

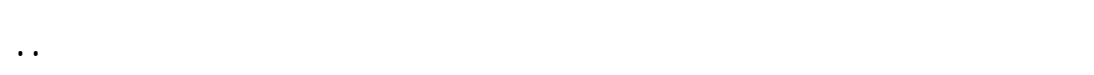

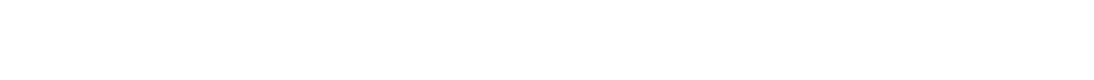
والإدارية التي تؤثر على أداء عضو هيئة التدريس.

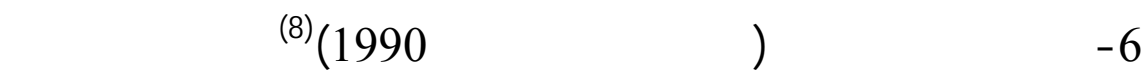

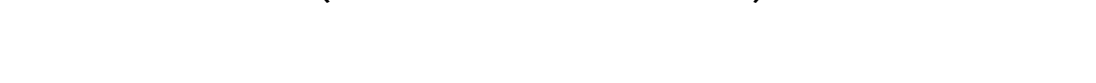

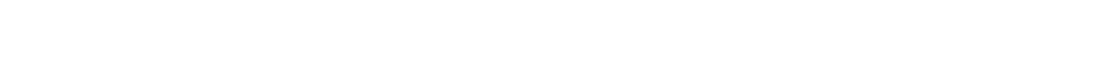


درلست إقليمية 5 (11)

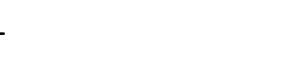

فيها، توصلت إلى مجموعة من النتائج حددت فيها أهم المشلك الت مي

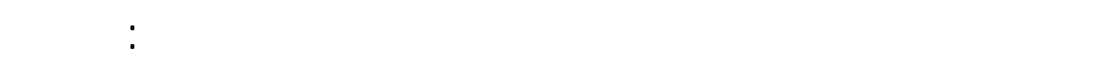

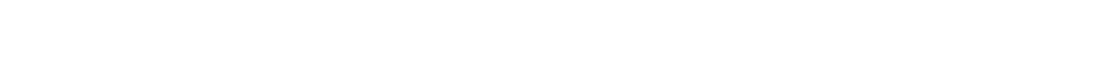

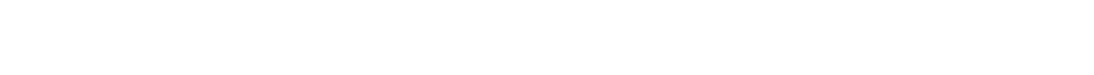

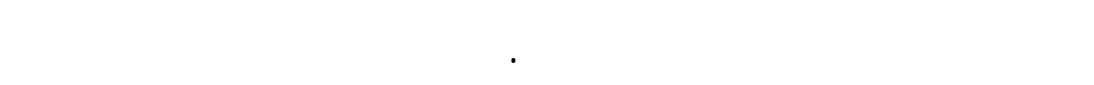

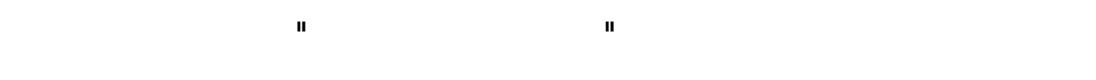

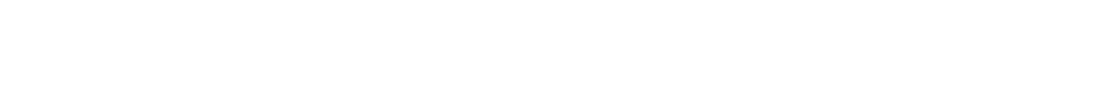

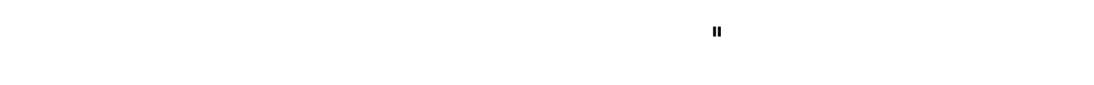

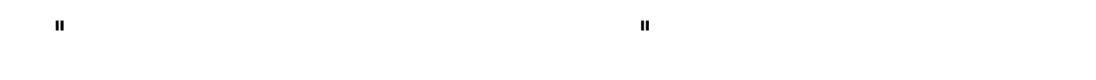

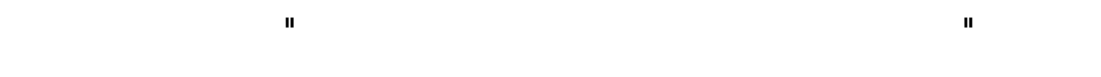

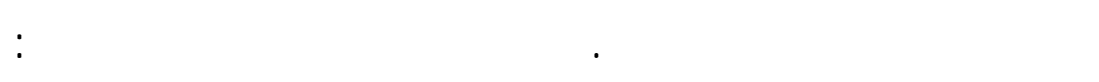

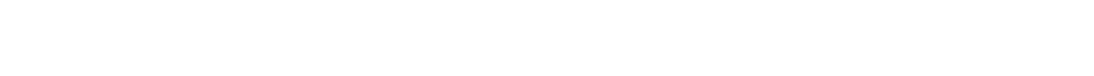

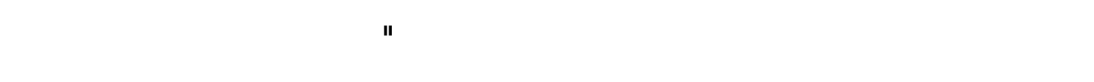

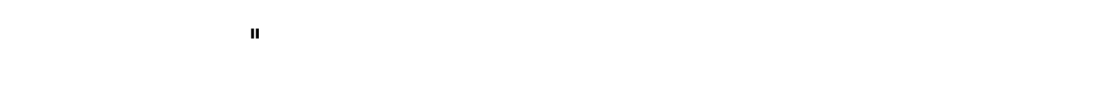

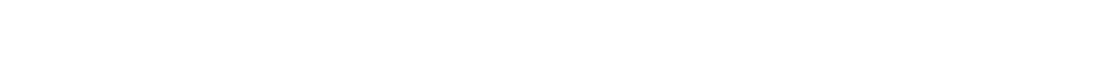

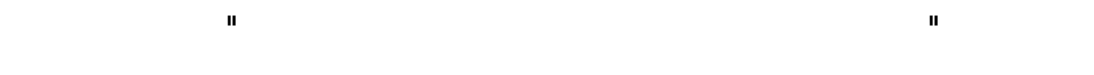
التجهيزات الفنية والمخبرية والوسالً التعليمية" في كلية التربية. وفي التئي

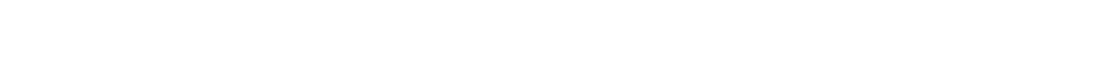

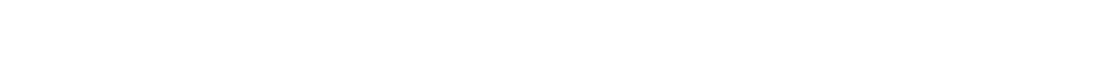

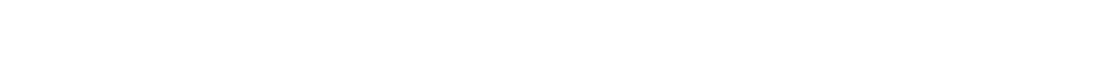

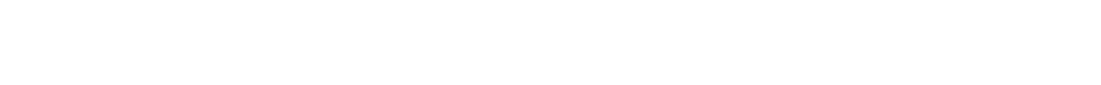

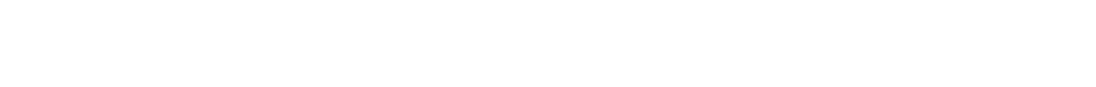

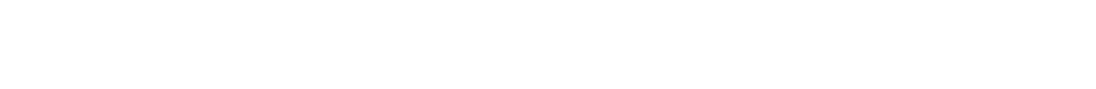


حول التعليم العالي لسمسيلسة وطنيةشلملة لطوير هذا التعليم بما يخدم خطط التمية الوطنية.

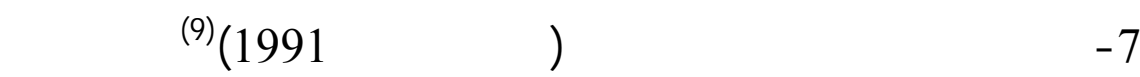

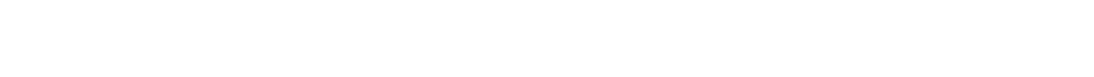

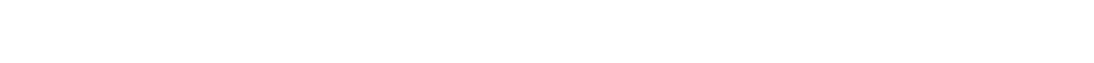

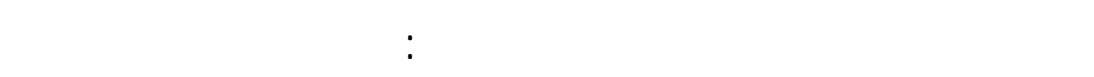

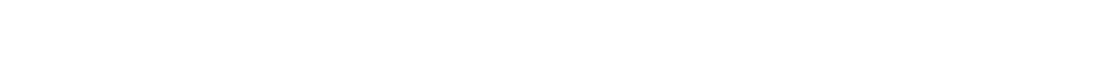

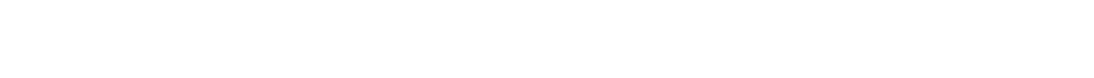

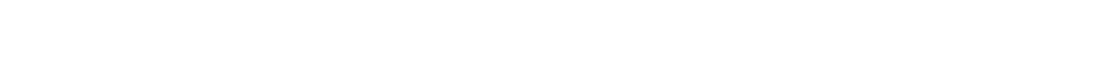

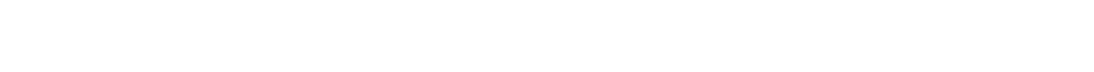

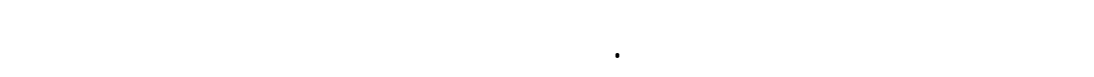

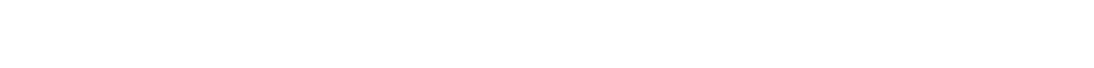

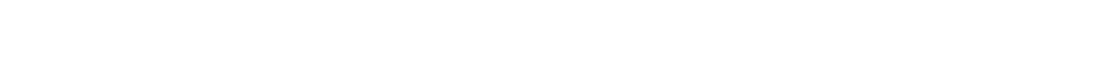
والمزلجية التي يم بها ظبيق اللوائح والقرارات.

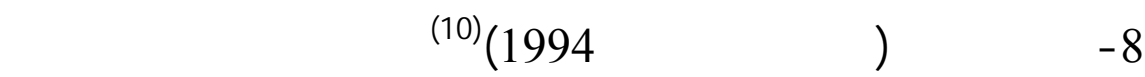

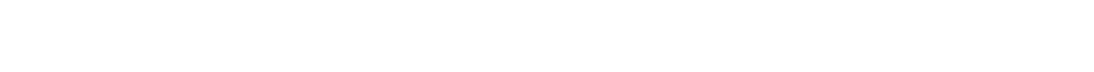

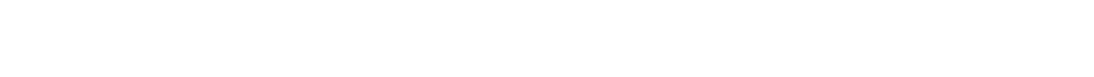

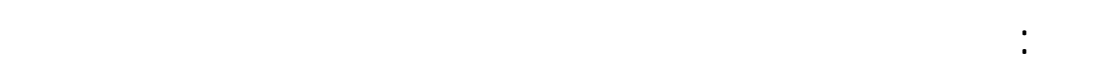

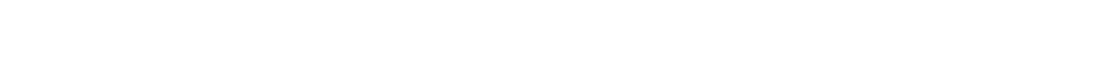

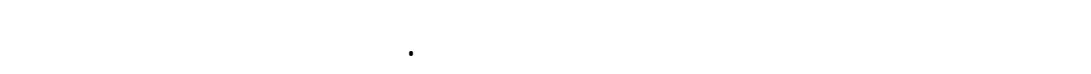

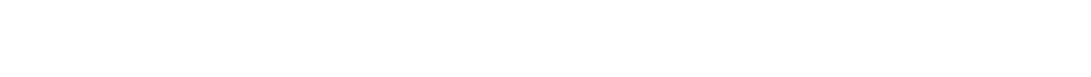

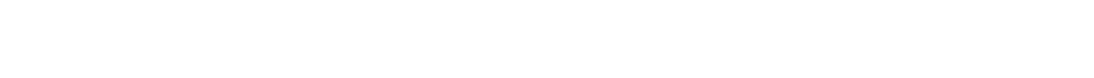

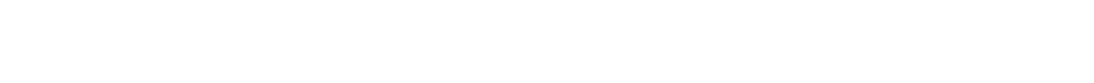

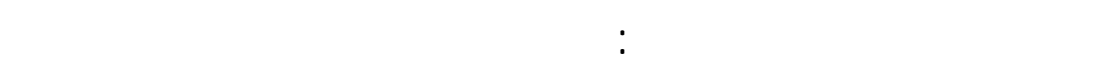


ولسٔلوب التدريب المتع في وجود الأعداد الكبيرة من الطلاب الذي لا

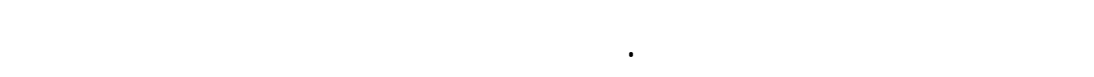

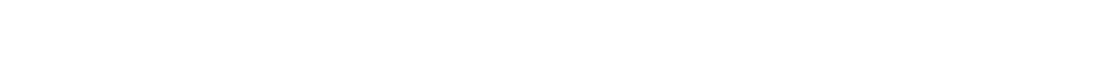

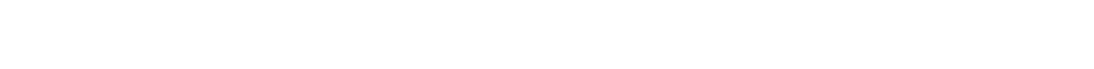

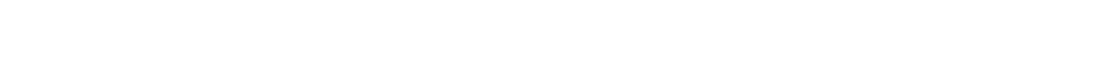

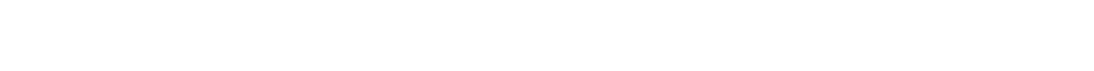

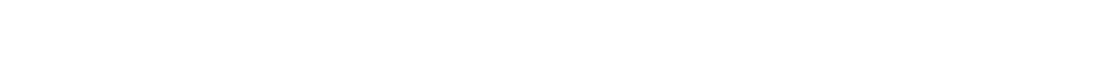

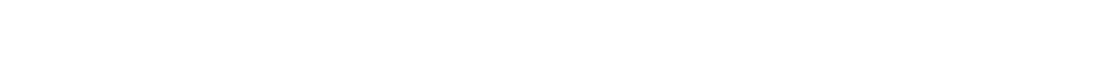

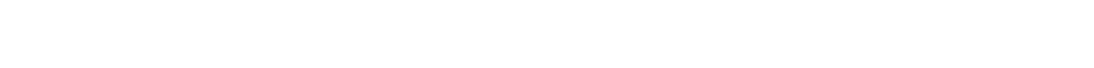

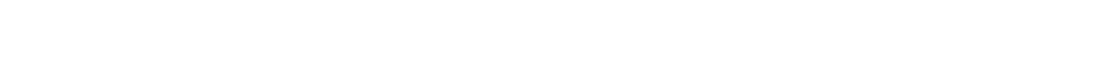

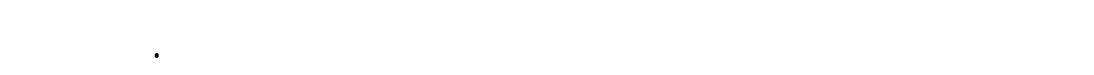

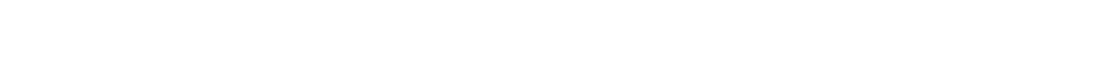

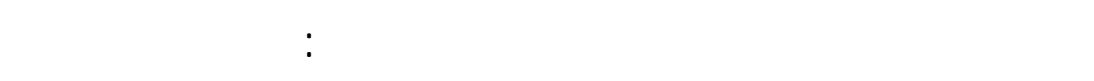
الإدارية المتبعة في الجلمعة والتي تعبق إنجاز معلملإلات أعضاء العاء هيئة

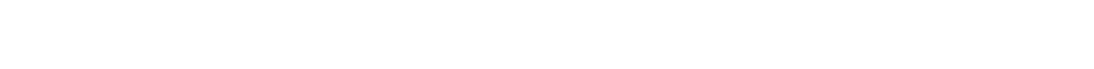
مشاركة أعضاء هيئة التدربيس للقيادات الإدارية في التخاذ الق ـرارات الإري

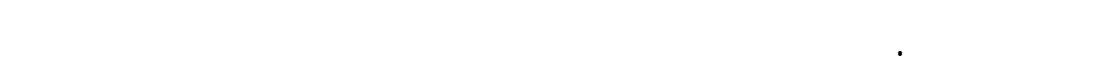

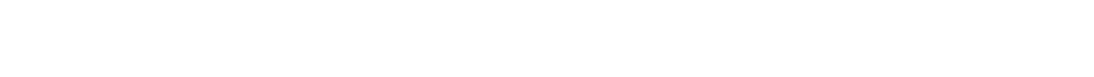

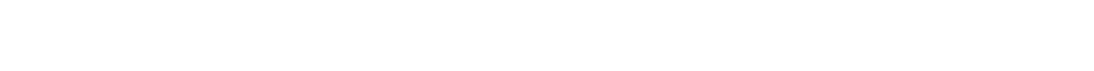

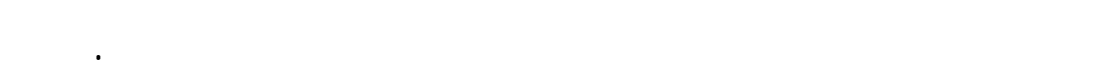

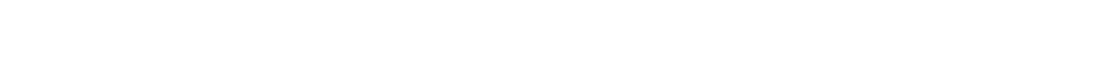

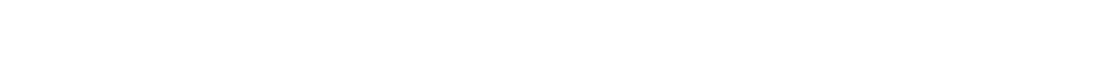

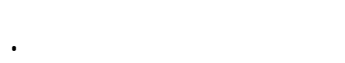


لجرت روزماري كليف (Rose mary Cliff 1975) (11) درلس مة ف مي

\section{ب) الدرلمات الأجنبية:}

جلمعة جنوب كاليفورنيا بالولايت المتحة الأمريكية من ألجل تحسيد أه م

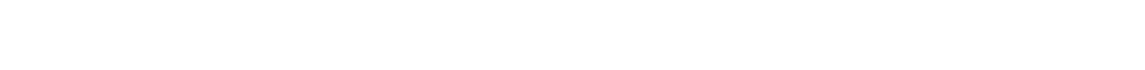

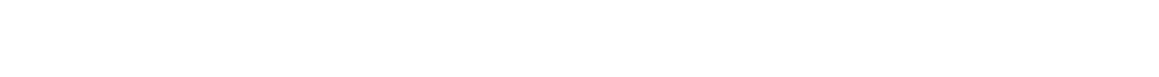

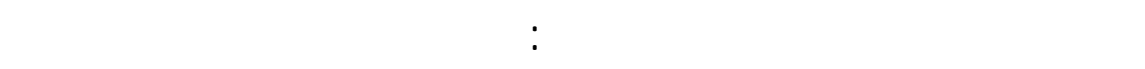

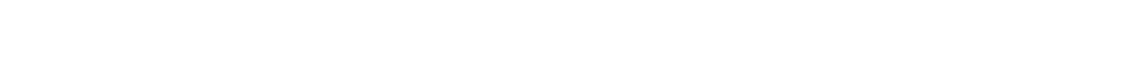
إدارة الجلمعة، كما بررزت مشكلة الفاوت في لأسلوب التعلمل مع أعضاء العضاء

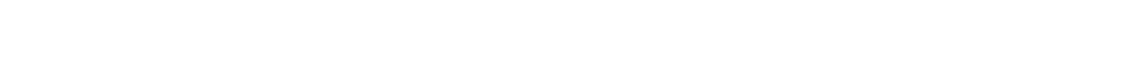

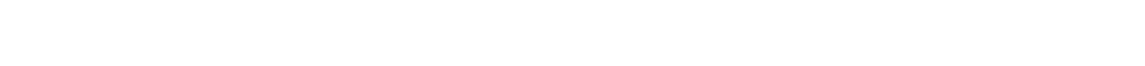
التي يقوم بأدائها أعضاء هيئة التدريس. كما لجربت ليندا موكسلي (Linda Moxley 1977) (12) درلسة هدفت إله ملعرفة المشلكل التي تولجه التدربيس وتسبب عدم الرض لاء ال _وظيفي،

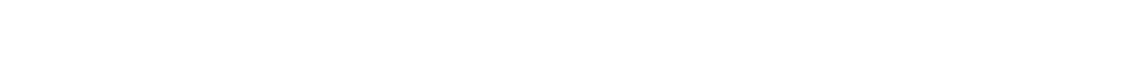

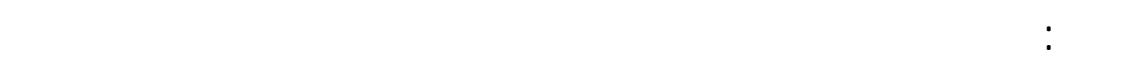
رواتب هيئة التدريب، وتلني مستوى الإيشاد العلمي، وعدم توافر الوقت الكالفي لأعضاء هيئة التدريس للقيلم بمهلمه الوظيفية المرتبط ـة بعمله م

أما الدرلسة التي لجراها جح سس سيجنلر 1983 (13) (Jesse Seegniller بالجلمعة. على أعضاء هيئة التدريس في كلية Eastern Utah University لمعرف ـة المبلة

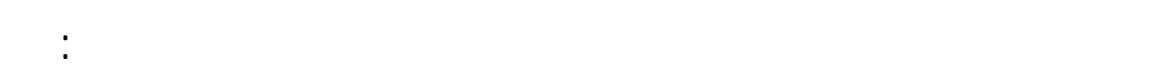

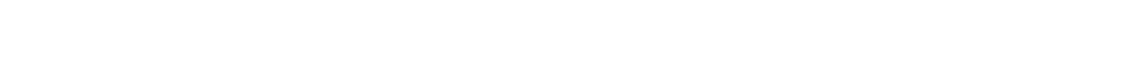

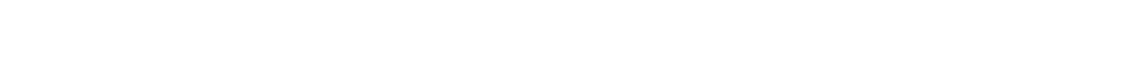
والندوات العلمية، وأن الجلمعة تولجه مشكلة فقدان الاتصل والتهل التعاون بين 


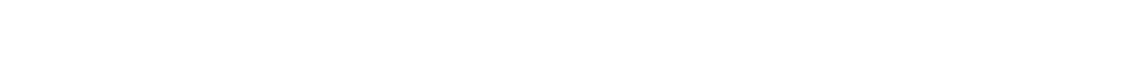

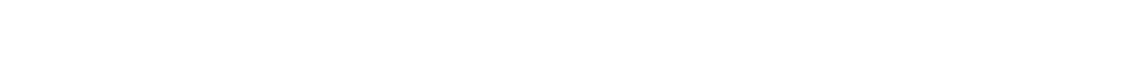
التدربيس وعدم ملاعمتها مع مظلبك الحملت الحيلة ومكانة المعلم الجلمعي.

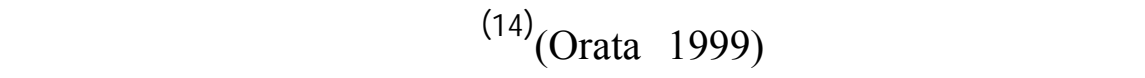

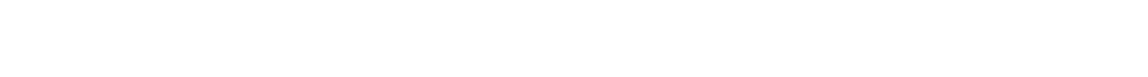

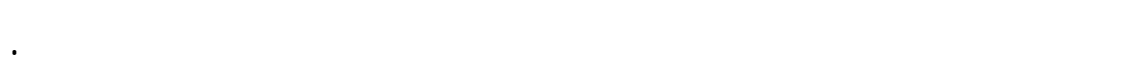

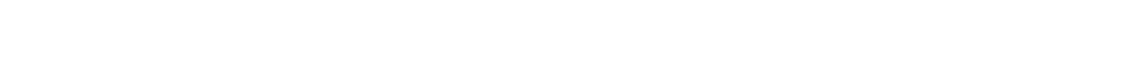

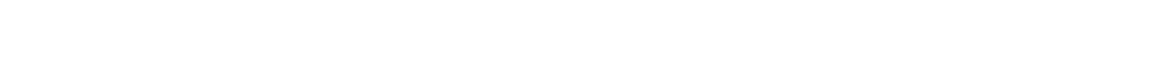

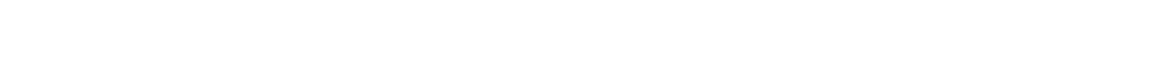

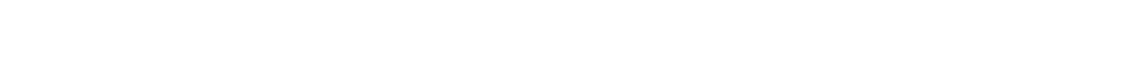

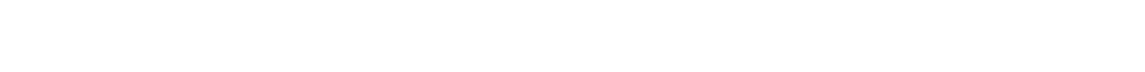

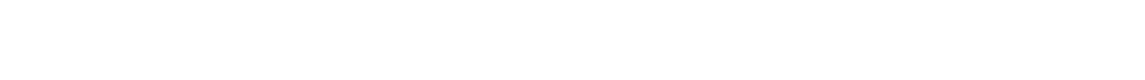

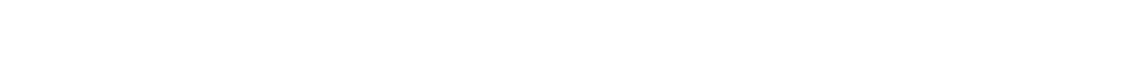

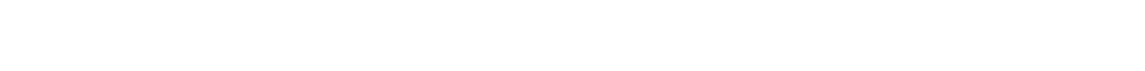

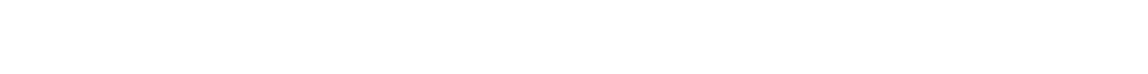

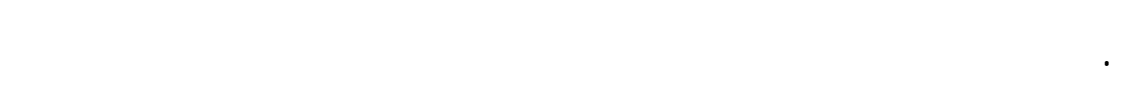

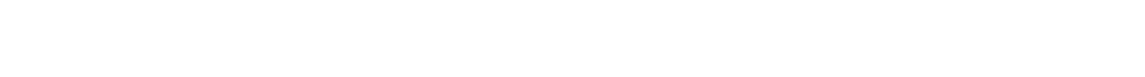

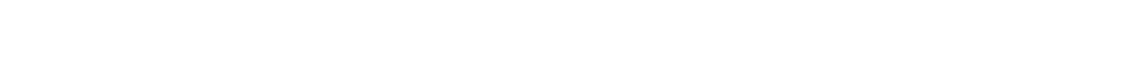

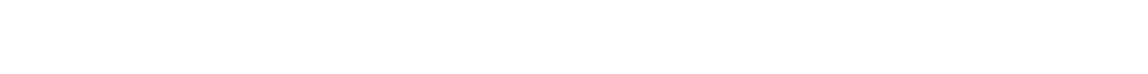

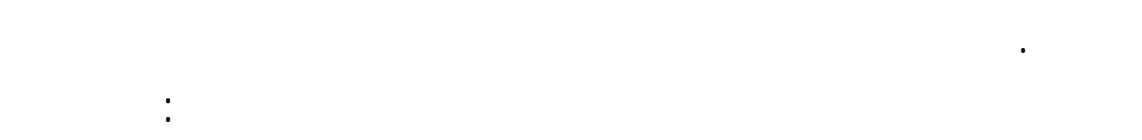

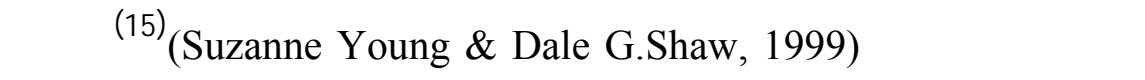
هدفت إلى الكثف عن عولمل فاعلية التدربيس ف ي الكلي لـ التلمعي ـة 
بجلمعة كلورادو للشمالية North Clorado University وتعرضت في هذا للسيق لهشكلات أعضاء هيئة الت دربيس ف مي بيئ ـة التعل ـيم الج المعي

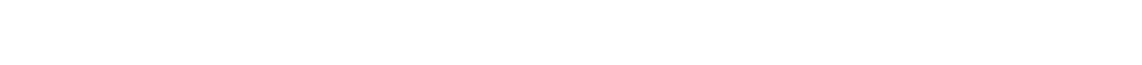
المقدمة في عمليتي التعليم والتعلم والبحث العلم مي الت مي تعتم ـد عل م في في

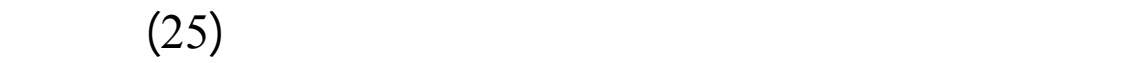

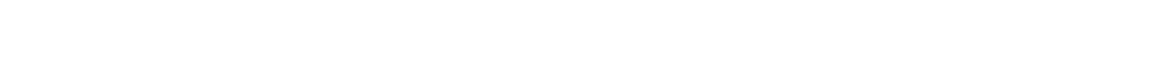
(912)طالبا لبيلن مدى فاعلية أعضاء هيئة التدريس في نقيم المقررات التي يدرسونها ولختيار أفضلهز لكل مقرر درلسي، وتوصلت الدرلسة إلى فيله

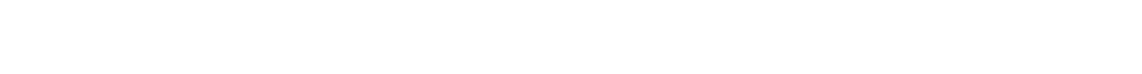

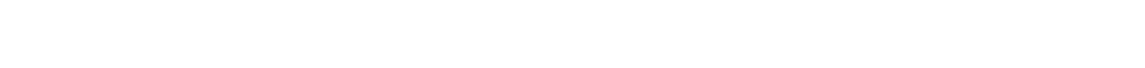

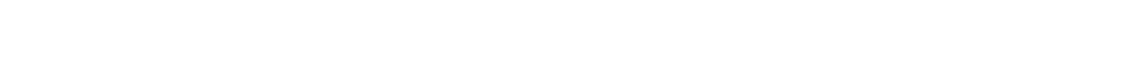
أعضاء هيئة التدريس يولجهون مشكلة التواصل والقاعل مع الطلاب مما

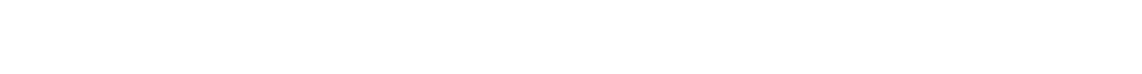
التدريس فهم الذين يولجهون مشكلة عدم القدرة على تظظيم محتوى المقرر

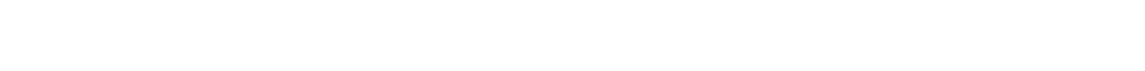

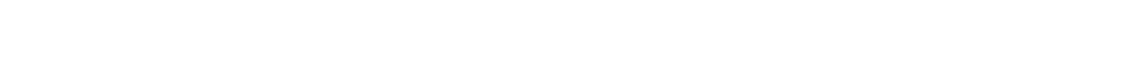
المنلمبة.

ومن خلال العرض للسابق للدرلست والبحوث التي لجريت في هـ ذذا الموضوع يمكن لستخلاص الآتي:

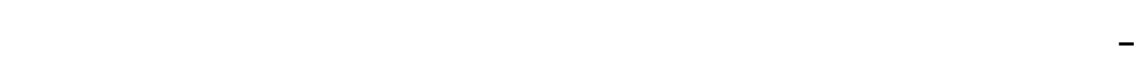

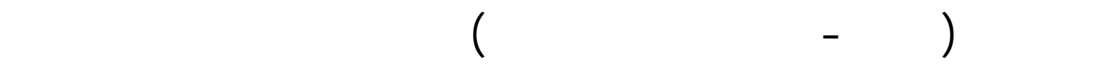
التدريس في مغظم الجلمعكت ومؤسست التعليم العالي.

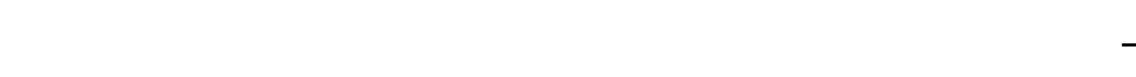
التدربيس من تلك المشلكل المتنوعة تؤثرسلبا على مستوى أدريائه الوظيفي. 


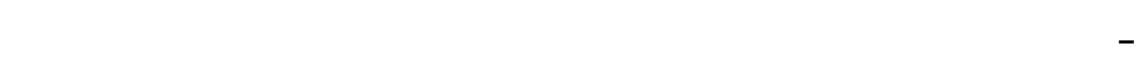

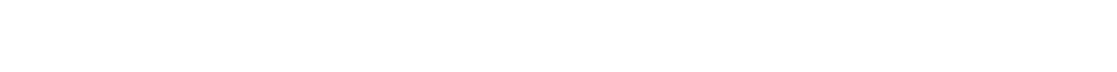

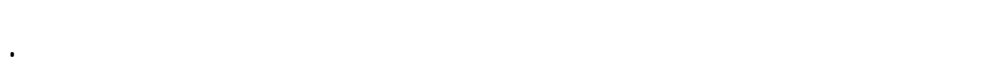

\section{المنهج والإجراءلت: أولا: المنهج:}

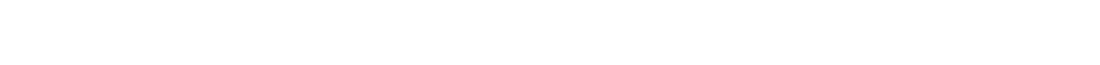

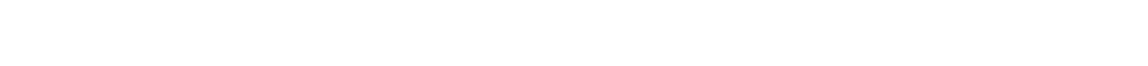

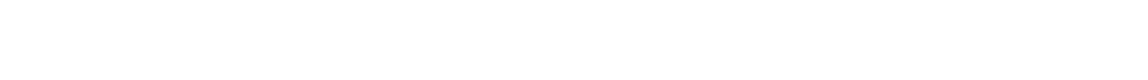
المشلكل وأنواعها.

\section{ثلنيا: الإجراعلت:}

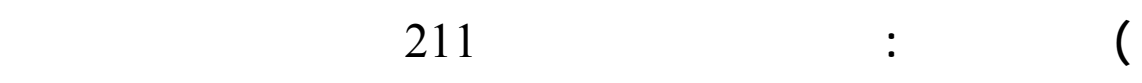

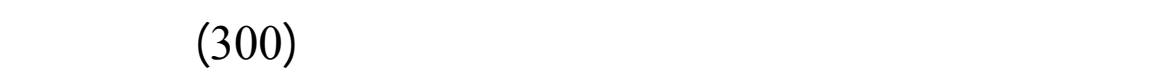

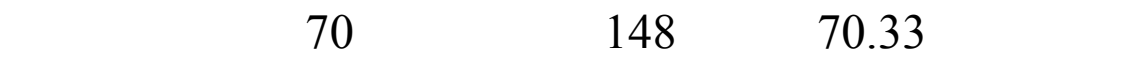

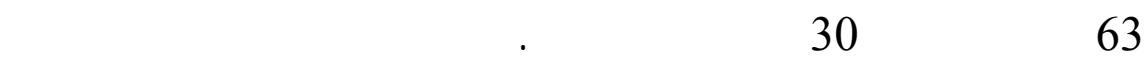

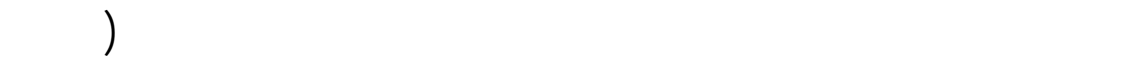
الجداول: 1، 2 2، 3، 3، 4). تكثف البيانت الواردة في (الجدول -1) أن العينة ممثلة تمثيلا جي ـدا

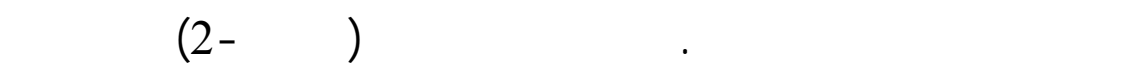

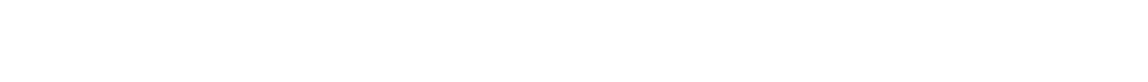
(النبة6.71.6). . وتشير البيانات الواردة في (الجدول -3) أن ثلثي مفردات

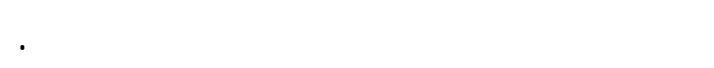


ب) أدلة الررلسة: قلم البلحث بتصميم لستبان لستفادت في صياغة مفردات

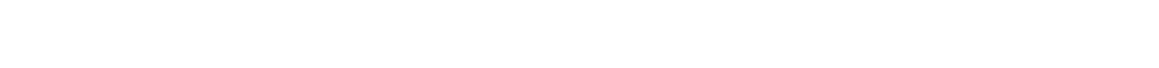

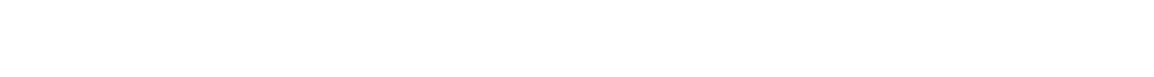

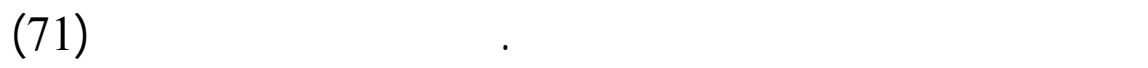

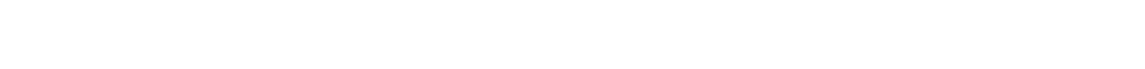

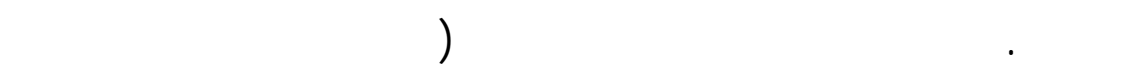

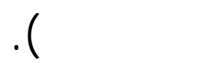
- العبارات الـ ـ 71 موزعة على خطس ـة مح اور لأسلس ية هـ مي على النحو التالي: - ع الئا * المشلكل في مجل التدربيس والإشش اد 25 عبارة العلهي:

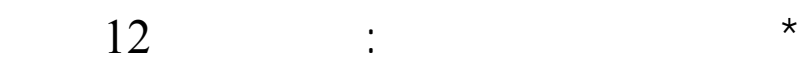

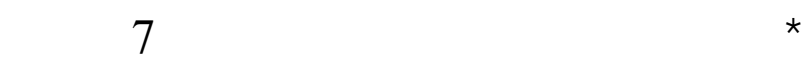

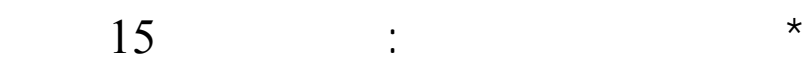

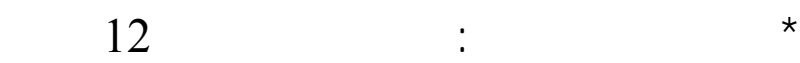


درلسك إقليمية 5 (11) مركز الدرلست الإقليمية

جرط (1): يوضنح توزيع عينة الررلسة مسب النوع والنخصص

\begin{tabular}{|c|c|c|c|c|c|c|}
\hline \multicolumn{2}{|c|}{ المجموع (ن - 211) } & \multicolumn{2}{|c|}{ إنلث (ن - 63) } & \multicolumn{2}{|c|}{ كور (ن - 148) } & العينة \\
\hline$\%$ & عدد & $\%$ & عدد & $\%$ & عدد & الخصصصت \\
\hline 5.2 & 11 & 3.2 & 2 & 6.1 & 9 & الانجليزبة \\
\hline 10.4 & 22 & 1.6 & 1 & 14.2 & 21 & وآللبها _a العريي ـ a a \\
\hline 2.4 & 5 & 6.3 & 4 & 7.00 & 1 & إعلد آل \\
\hline 6.6 & 14 & 4.8 & 3 & 7.4 & 11 & علم الفس \\
\hline 5.7 & 12 & 3.2 & 2 & 6.8 & 10 & المقو \\
\hline 5.2 & 11 & 6.3 & 4 & 4.7 & 7 & ت كنولوجيا \\
\hline 8.5 & 18 & 6.3 & 4 & 9.5 & 14 & زبراعية \\
\hline 10.9 & 23 & 20.6 & 13 & 6.8 & 10 & علم الجتماع \\
\hline 5.7 & 12 & 4.8 & 3 & 6.1 & 9 & علوم النسيير \\
\hline 3.8 & 8 & 4.3 & 3 & 3.4 & 5 & علوم لتصالية \\
\hline 5.7 & 12 & 1.6 & 1 & 7.4 & 11 & هنسة مدنية \\
\hline 3.3 & 7 & 6.3 & 4 & 2. & 3 & النسير ـ ـلم آل ـ ـم \\
\hline 9.00 & 19 & 14.3 & 9 & 6.8 & 10 & 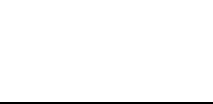 \\
\hline 4.3 & 9 & - & - & 6.1 & 9 & علوم تجاربة \\
\hline 5.2 & 11 & 9.5 & 6 & 3.4 & 5 & كيمياءصناعية \\
\hline 8.1 & 17 & 6.3 & 4 & 8.8 & 13 & مكيلنك \\
\hline
\end{tabular}


جرل (2): توزيع عينة الدرلسة مسب النوع والمس الفليف

\begin{tabular}{|c|c|c|c|c|c|c|}
\hline \multicolumn{2}{|c|}{ المجموع (ن- 211) } & \multicolumn{2}{|c|}{ إلث (ن- 63) } & \multicolumn{2}{|c|}{ نكور (ن - 148) } & العينة \\
\hline$\%$ & عدد & $\%$ & عدد & $\%$ & عدد & الهس الظليف \\
\hline 14.7 & 31 & 14.5 & 02 & 13.5 & 20 & لأستاذ تعلم عالي ومحاضر \\
\hline 71.6 & 151 & 57 & 32 & 80.4 & 119 & بالستاذ مساعد ومكل \\
\hline 12.8 & 27 & 30.2 & 19 & 5.4 & 8 & الستاذ مهنس \\
\hline 0.9 & 2 & 1.6 & 1 & 0.7 & 1 & غير مبين \\
\hline
\end{tabular}

جرط (3): توزيع عينة الررلسة هسب النوع وسنولت الخبرة

\begin{tabular}{|c|c|c|c|c|c|c|}
\hline \multicolumn{2}{|c|}{ المجموع (ن - 211) } & \multicolumn{2}{|c|}{ إنثل (ن - 63) } & \multicolumn{2}{|c|}{ نكور (ن - 148) } & العينة \\
\hline$\%$ & عدد & $\%$ & عدد & $\%$ & عدد & سنولت الخبرة \\
\hline 33.6 & 71 & 26.9 & 17 & 36.5 & 54 & عشرسنولت فأل \\
\hline 66.4 & 140 & 73 & 46 & 63.9 & 94 & كٔثرمن عشرسنوات \\
\hline
\end{tabular}

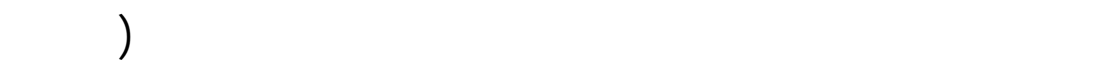

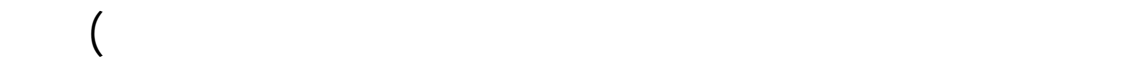

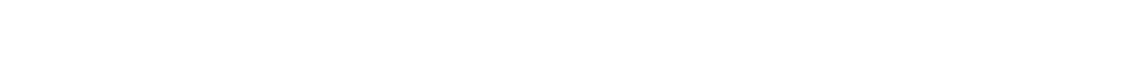

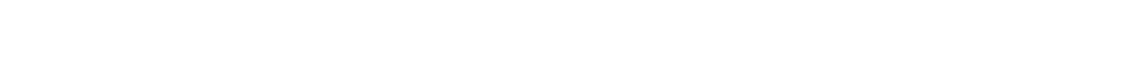

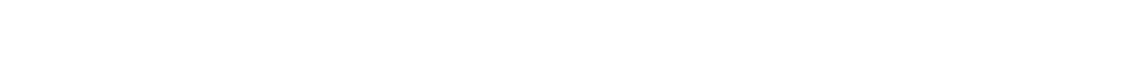

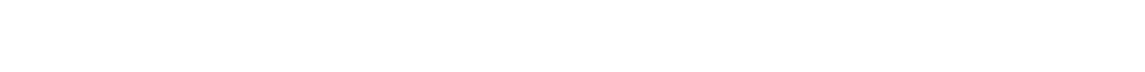

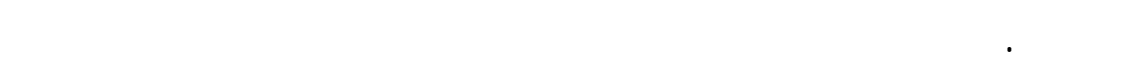
وأضف مشكلات لخرى لُجمع المحكمون على أهميتها. 
ج - الصوق: بعد أن قلم البلحثن بإعداد لستبيلن الدرلسة قم عرضها على فيلى

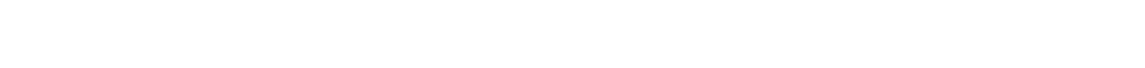

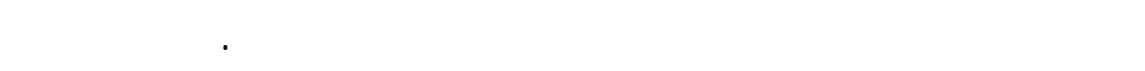

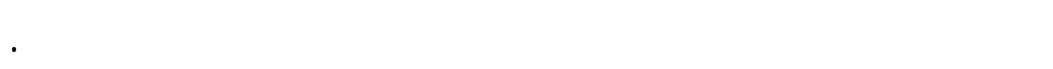

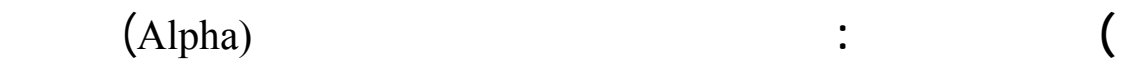

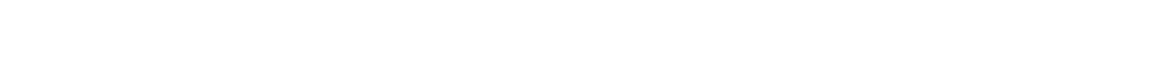

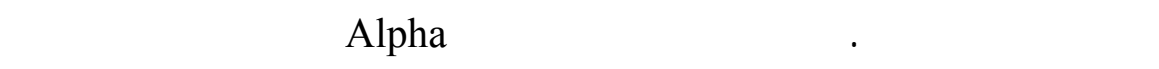

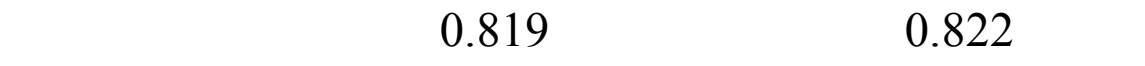

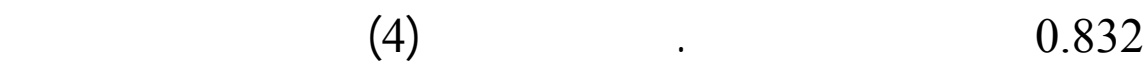

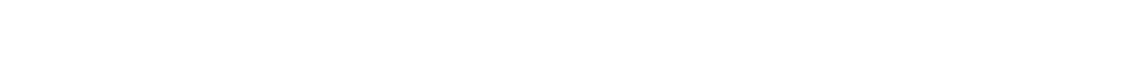

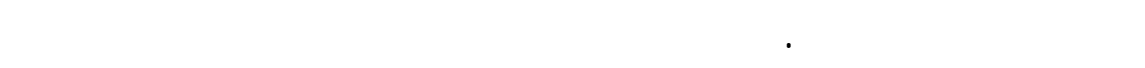

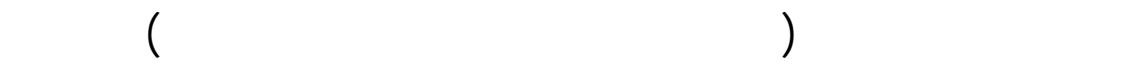

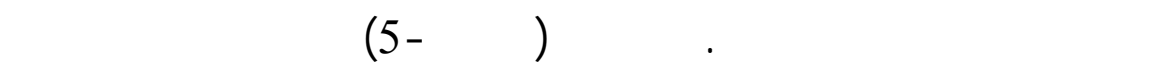

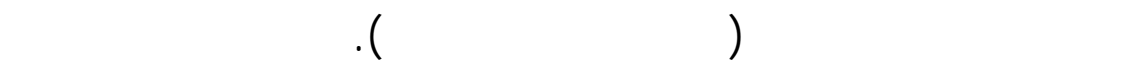

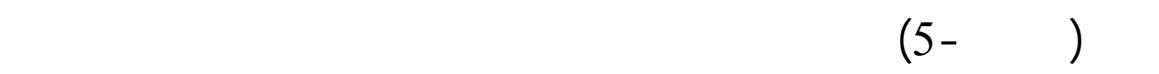

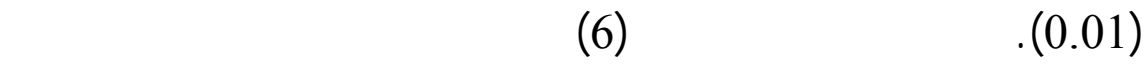
الدرجة الكلية ومقاييس الدرلمة الفرعية.

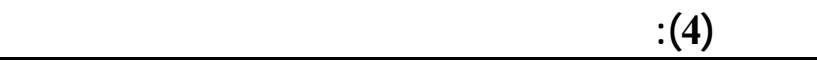

\begin{tabular}{|c|c|c|c|}
\hline لإنلث & النكور & العينة الكلية & المجموعلت \\
\hline$(63=\dot{ })$ & $(148=i)$ & $(211=i)$ & المغيرك \\
\hline 0.842 & 0.846 & 0.843 & - المشالىف فمل التربس \\
\hline 0.907 & 0.928 & 0.923 & - المشالى فمجل البهث العلم \\
\hline 0.864 & 0.847 & 0.852 & - مشكلات النهو المهن. \\
\hline 0.911 & 0.874 & 0.884 & - المشالى لإدارية والمالية. \\
\hline 0.853 & 0.844 & 0.845 & - المشلا الجتماعية. \\
\hline
\end{tabular}


د. معراج عبد القادر المشلكل التي تجابه عضو هيئة التدربس

جدط (5): يوضح معالملات الارتبلا الظلية بين الفقليس الفرعية المشكلة للستبيلن الررلسة

\begin{tabular}{|c|c|c|c|c|c|}
\hline (5) & (4) & (3) & (2) & (1) & المقلييس الفرعية \\
\hline 0.566 & 0.579 & 0.411 & 0.542 & & - المشلى ف مجل التريس \\
\hline * & $*$ & $*$ & & & \\
\hline 0.438 & 0.598 & 0.532 & & & - المشالك في مجل البهث العلي \\
\hline 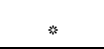 & * & $*$ & & & \\
\hline 0.391 & 0.494 & & & & -مشكلات النمو المهن. \\
\hline$*$ & $*$ & & & & \\
\hline \multirow{3}{*}{0.581} & & & & & - المشلى المالية ولإدارية. \\
\hline & & & & & \\
\hline & & & & & - المشلى الجتماعية. \\
\hline
\end{tabular}

جطر (6) يوضح معالمات لارتبلا بين المكونلت الفرعية والدرجة الكلية عل الفقيلس

\begin{tabular}{|c|c|}
\hline معالل الارتبلا & الفقليي الفرعية \\
\hline$* * * * 0.844$ & - المشال في مجل التدربس \\
\hline$* * 0.763$ & - مشكلات في مجل البهث العلي \\
\hline$* * 0.632$ & - مشكلات النمو المهني. \\
\hline$* * 0.805$ & - الهشال الإداربة والمالية. \\
\hline$* * 0.759$ & - المشال الجتماعية. \\
\hline
\end{tabular}

ومما يزيد من درجة الاتسق الارتبطلت الدالة فيما وراء 0.01 بين

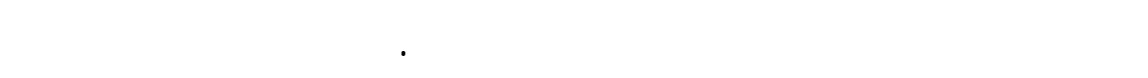
إلى لستخدلم هذه الأدلة في هذه الدرلسة وفي درلسلت عالية حلية

0101 معالل الارتبلا ل عندمستوى * 


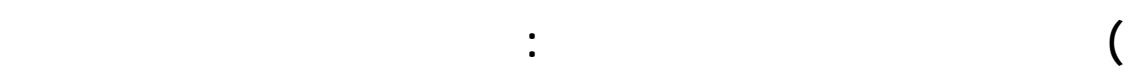

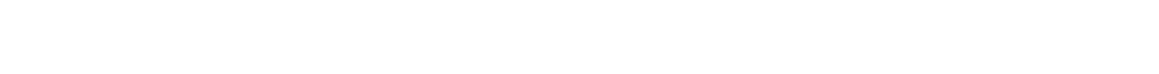

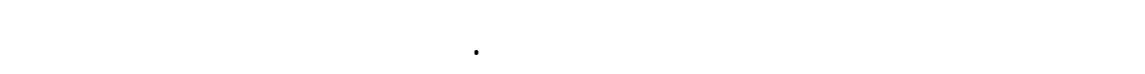

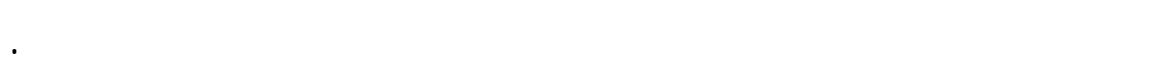
لمتمر جمع البيانات ورلبةشهرين.

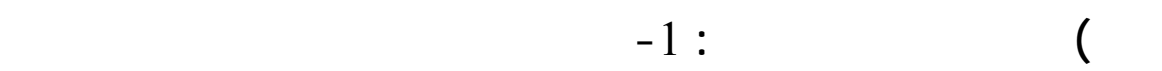

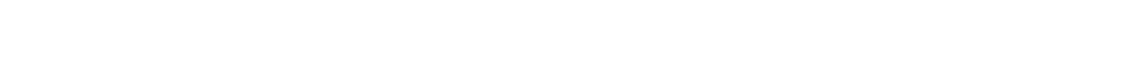

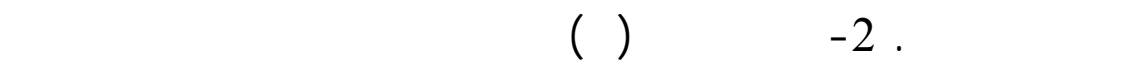

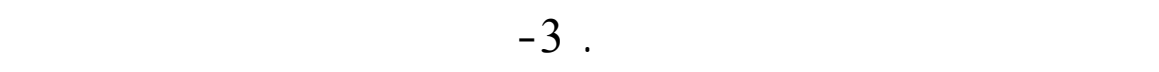
المئوية .. و "كا"' ودلالتها على كل بند من بنود المستبيان للعينة الكلية.

\section{عرض النتائج وفسيرها:}

سسوف تعرض نتائج الدرلسة باللشكل الذي يحقق الأهداف وذك على النحو الآتي: 1 - نتائج الفروق بين النكور والإن لث مـن أعض اء هيئ هة الت دريس في حجم المشلكل الموجونة. 2 - نتنائج الفروق بـ بـن ذوي الخب ـرات الحيثة والقديم ة ف في حج م المشلكل الموجولة.

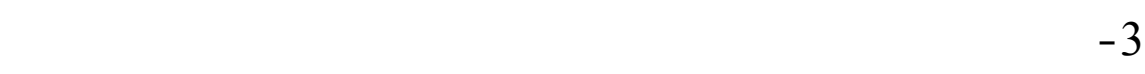

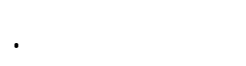

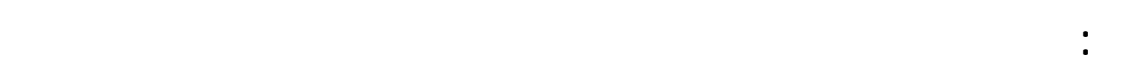
الموجوة. 
يتب ـين مه ن (الج دول -7) المتوس طلت والانحراف ـات المعياريــة

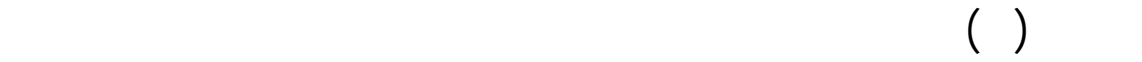

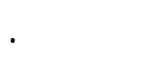

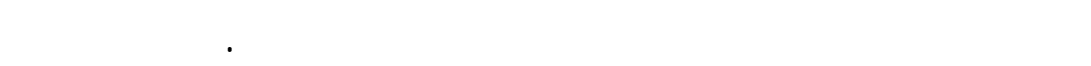

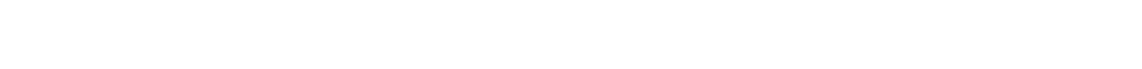

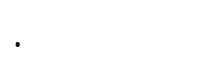
ثلنياً: نتائج الفروق بين ذوي الخب ـرات الحيث ـة والقديم ـة ف مي حج م

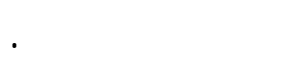

\section{جطل (7) يوضح المتوطلت (م) ولانحرافلت المعياربة (ع) وقيم (ت)

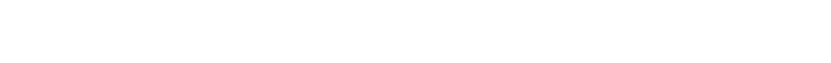

\begin{tabular}{|c|c|c|c|c|c|c|}
\hline \multirow[t]{2}{*}{ الدلالة } & \multirow{2}{*}{ قيم (ت) } & \multicolumn{2}{|c|}{ إنلث: 63} & \multicolumn{2}{|c|}{ نكور: 148} & العينة والمؤشرات \\
\hline & & $\varepsilon$ & $A$ & $\varepsilon$ & $A$ & المتغيرت \\
\hline غير دالة & 0.56 & 9.05 & 53.10 & 9.77 & 53.88 & - حجم الثشلى فمجل \\
\hline غير دالة & 1.27 & 5.11 & 31.98 & 6.37 & 30.83 & - حبه المشالى في مج لـ ل \\
\hline غير دالة & 1.01 & 3.52 & 17.41 & 3.71 & 16.86 & - حبه المشالى المتحلة \\
\hline غير دالة & 0.79 & 7.28 & 35.63 & 6.49 & 36.43 & - حبم الهشال الإدارية \\
\hline غير دالة & 0.32 & 6.46 & 25.32 & 5.69 & 25.03 & - حجم العشالى الجتماعية \\
\hline غير دالة & 0.09 & 25.34 & 161.84 & 25.72 & 16.182 & - الدرجة الكلية \\
\hline
\end{tabular}




\section{جطط (8) يوضنح المتوسلت ولانحرلك المعيارية قويم (ت) ودلالانها}

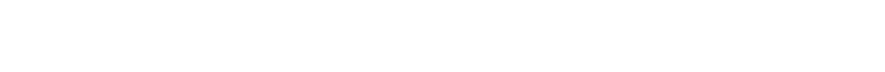

\begin{tabular}{|c|c|c|c|c|c|c|}
\hline \multirow[t]{2}{*}{ الدעالة } & \multirow[t]{2}{*}{ قيم } & \multicolumn{2}{|c|}{ 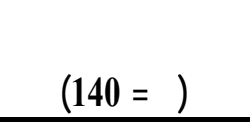 } & \multicolumn{2}{|c|}{ عشرسنواتفألى } & \multirow{2}{*}{ العينة والمؤشرات } \\
\hline & & $\varepsilon$ & م & $\varepsilon$ & م & \\
\hline غير دالة & 1.03 & 8.87 & 53.16 & 10.76 & 54.59 & مجل التريس المشلك في \\
\hline غير دالة & 0.40 & 5.84 & 31.06 & 6.44 & 31.41 & مجل البه العلى المشلف \\
\hline غير دالة & 1.21 & 3.67 & 16.81 & 3.60 & 17.45 & - حجم المشالى المتعلة \\
\hline غير دالة & 0.65 & 6.49 & 35.98 & 7.21 & 36.62 & - حبم المشلى الإدارية \\
\hline غير دالة & 1.29 & 5.59 & 24.73 & 6.47 & 25.85 & - الاجماعم المشلى \\
\hline غير دالة & 1.12 & 23.39 & 160.68 & 29.32 & 164.85 & - الدرجة الهلية \\
\hline
\end{tabular}

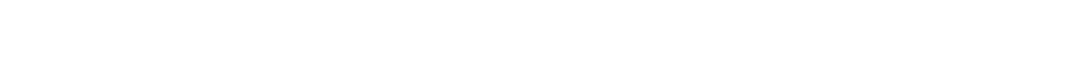

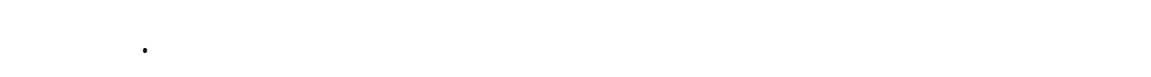

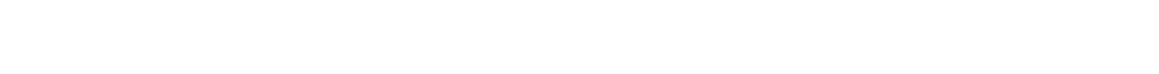

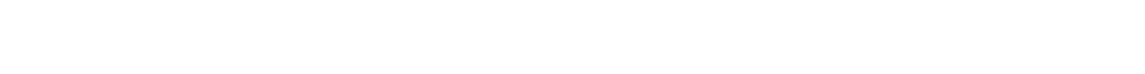

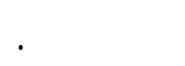


ثالثاًا: حهم المشلكل الفرعية ودرجة الموافقة عليهامن خلال نتائج كا²:

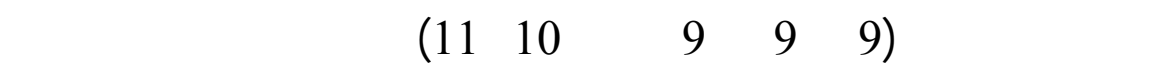

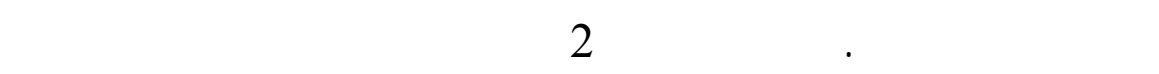
عدم الموافقة.

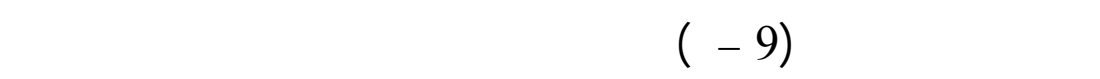

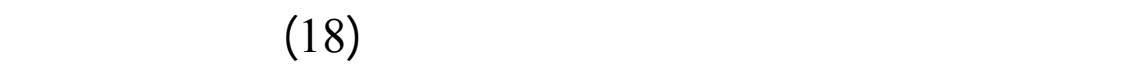

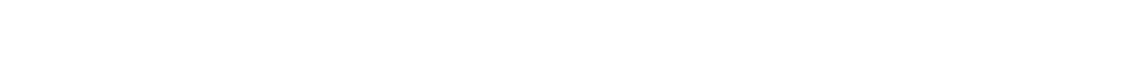

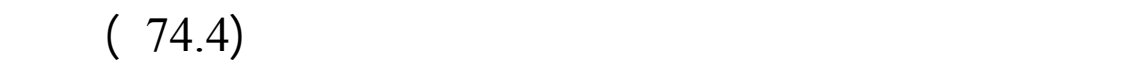

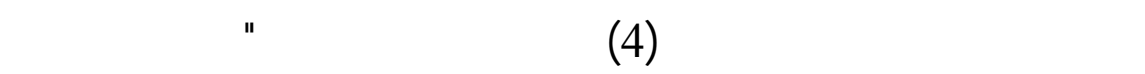

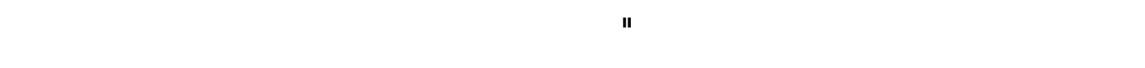

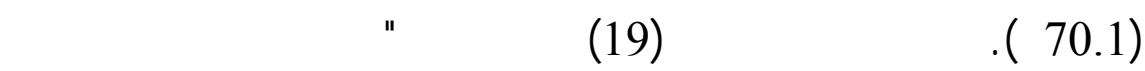

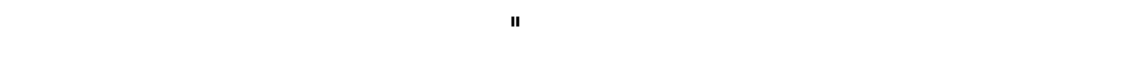

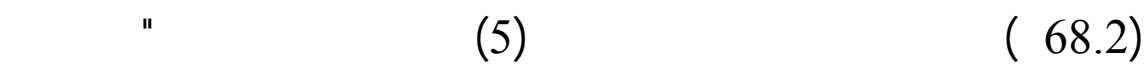

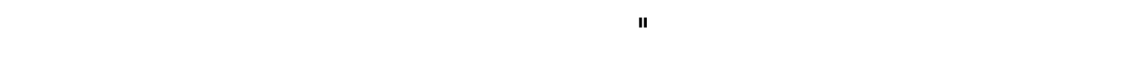

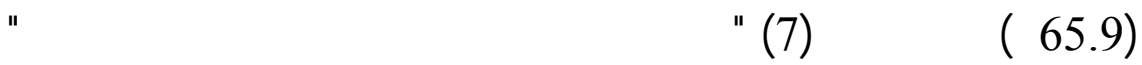

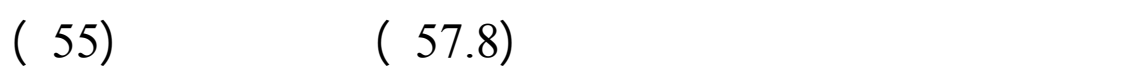

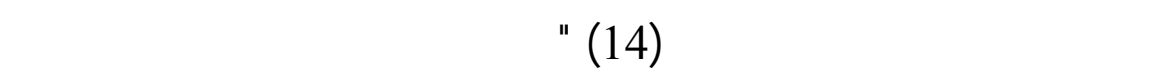

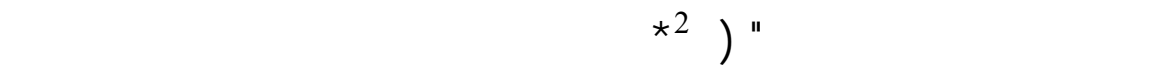

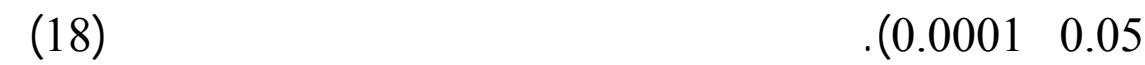

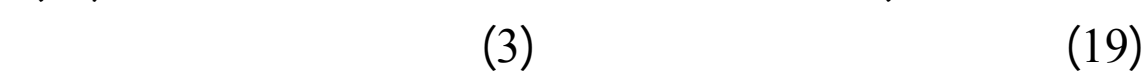

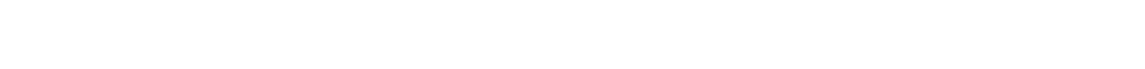

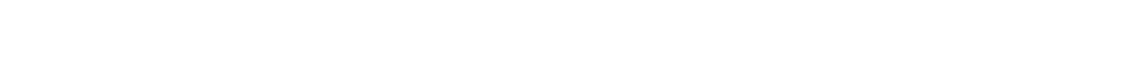

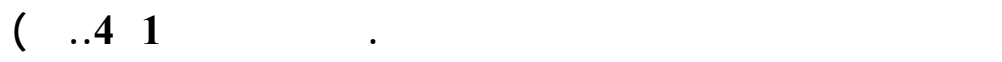


الوظيفي عند أعضاء هيئة التدربس.

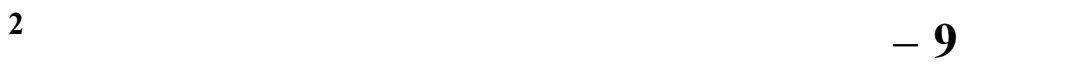
ودلاتها للمينة الكلية عل كلى مشكاة فرعية طن (مشكلات التدربس)

\begin{tabular}{|c|c|c|c|c|c|c|c|c|}
\hline \multirow{3}{*}{ الدلالة } & \multirow{3}{*}{${ }^{2}$} & \multicolumn{6}{|c|}{ العينة الكلية (ن - 211) } & \multirow{3}{*}{ 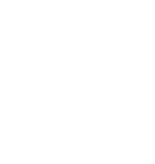 } \\
\hline & & \multicolumn{2}{|c|}{ غيرموانق } & \multicolumn{2}{|c|}{ إلى حدما } & \multicolumn{2}{|c|}{ مودُق } & \\
\hline & & $\%$ & عدد & $\%$ & عدد & $\%$ & عدد & \\
\hline 0.001 & 13.42 & 28.8 & 60 & 25.6 & 54 & 45.2 & 94 & 1 \\
\hline 0.04 & 6.28 & 24.2 & 51 & 35.1 & 74 & $37.0-$ & 78 & 2 \\
\hline 0.01 & 8.67 & 28.9 & 61 & 41.7 & 88 & 26.5 & 56 & 3 \\
\hline 0.0001 & 133.33 & 17.5 & 37 & 11.4 & 24 & 70.1 & 148 & 4 \\
\hline 0 & 111.79 & 8.5 & 18 & 24.6 & 52 & 65.9 & 139 & 5 \\
\hline 0.003 & 11.85 & 22.3 & 47 & 41.2 & 87 & 33.2 & 70 & 6 \\
\hline 0.0001 & 84.61 & 6.6 & 14 & 33.6 & 71 & 57.8 & 122 & 7 \\
\hline 0.01 & 8.57 & 37.9 & 80 & 37.9 & 80 & 23.7 & 50 & 8 \\
\hline غير دالة & 1.52 & 30.3 & 64 & 36.5 & 77 & 30.8 & 65 & 9 \\
\hline 0.009 & 9.46 & 23.2 & 49 & 36.5 & 77 & 39.3 & 83 & 10 \\
\hline 0.03 & 6.82 & $28-$ & 59 & 41.2 & 87 & 29.4 & 62 & 11 \\
\hline 0.0001 & 26.99 & 49.3 & 104 & 22.7 & 48 & 26.1 & 55 & 12 \\
\hline غير دالة & 1.68 & 36.5 & 77 & 30.8 & 65 & 29.9 & 63 & 13 \\
\hline 0.0001 & 50.02 & 16.6 & 35 & 27.5 & 58 & 55- & 116 & 14 \\
\hline غير دالة & 1.77 & 30.3 & 64 & 30.8 & 65 & 27- & 78 & 15 \\
\hline غير دالة & 4.16 & 27- & 57 & 33.2 & 70 & 38.4 & 81 & 16 \\
\hline 0.0001 & 18.52 & 20.9 & 44 & 44.1 & 93 & 29.4 & 62 & 17 \\
\hline 0.0001 & 165.32 & 9.5 & 20 & 15.2 & 32 & 74.4 & 157 & 18 \\
\hline 0.001 & 119.84 & 12.8 & 27 & $18-$ & 38 & 68.2 & 144 & 19 \\
\hline 0.0001 & 51.91 & 18.5 & 39 & 25.1 & 53 & 56.4 & 119 & 20 \\
\hline غير دالة & 5.12 & 27.5 & 58 & 31.3 & 66 & 39.8 & 84 & 21 \\
\hline 0.04 & 6.44 & 35.5 & 75 & 24.2 & 51 & $37-$ & 78 & 22 \\
\hline 0.001 & 34.04 & 23.7 & 50 & 23.2 & 49 & 51.7 & 109 & 23 \\
\hline 0.05 & 5.89 & 21.3 & 45 & 25.1 & 53 & 50.7 & 107 & 24 \\
\hline غير دالة & 3.03 & 38.4 & 81 & 25.1 & 53 & 33.6 & 71 & 25 \\
\hline
\end{tabular}




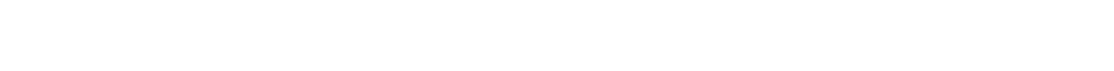

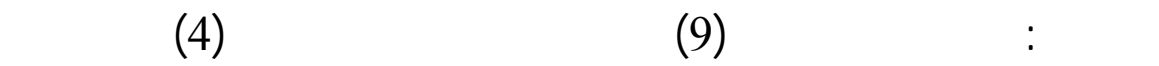

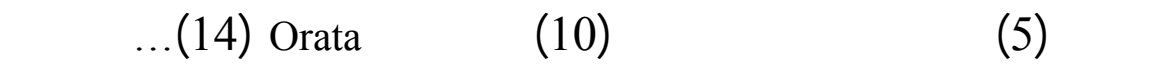

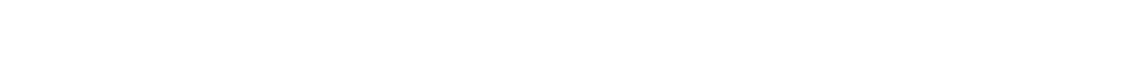

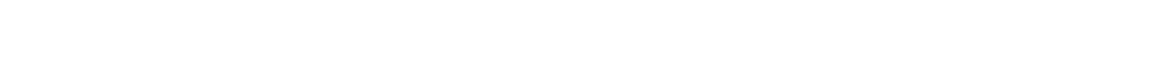
بروزَ في مجل التدريب .

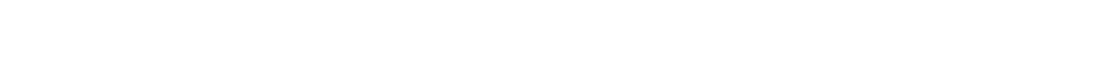

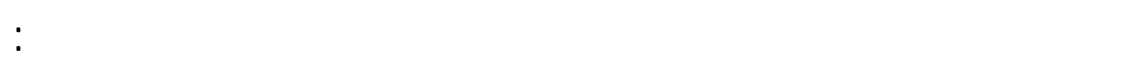

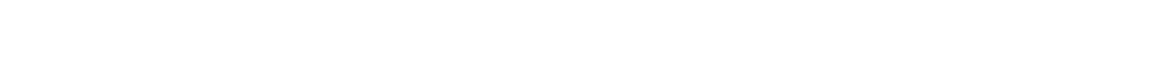

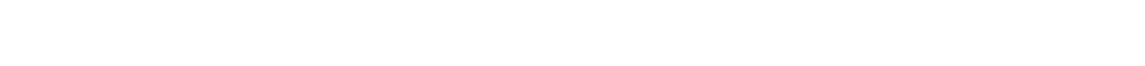

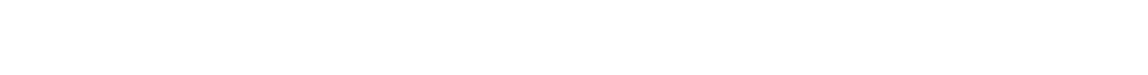

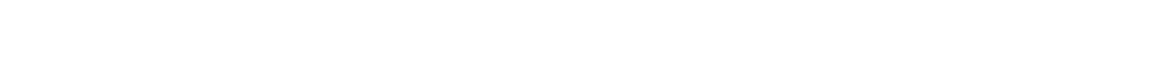

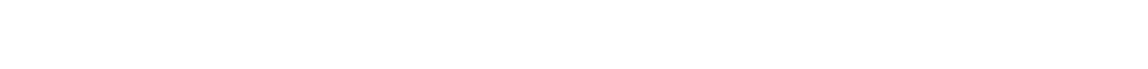

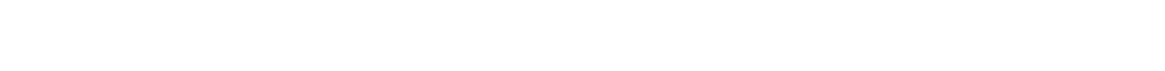
المرجوة منها (16).

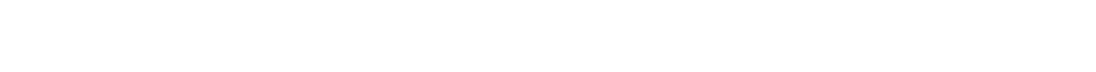

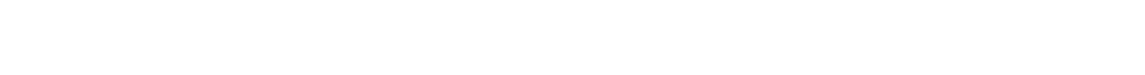

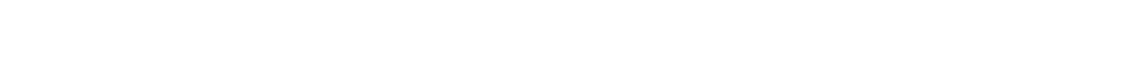

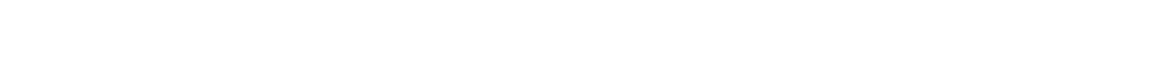

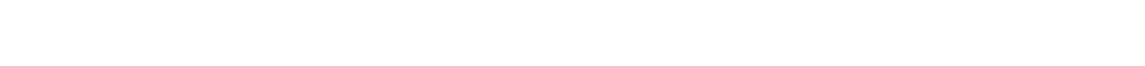

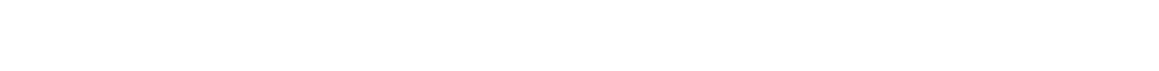

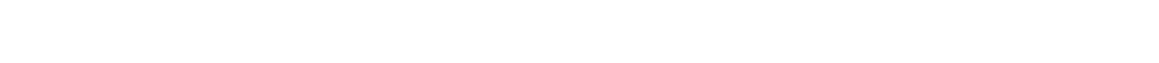

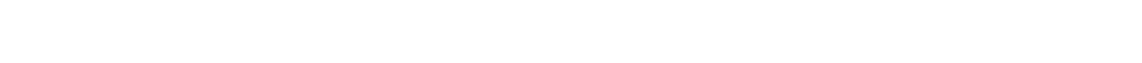

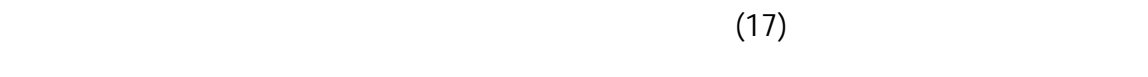


درلست إقليمية 5 (11)

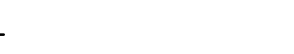

عضو هيئة التدربيس دوراً لأسلسياً في حفز الط للاب وقف اعلهم لعملي ـة التعلم.

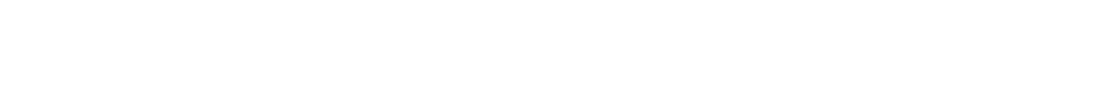

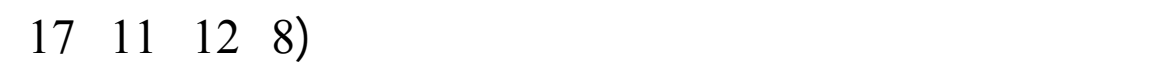

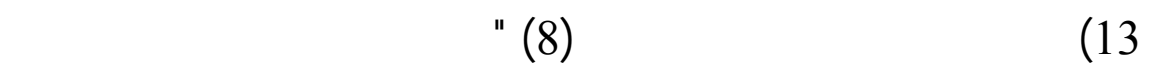

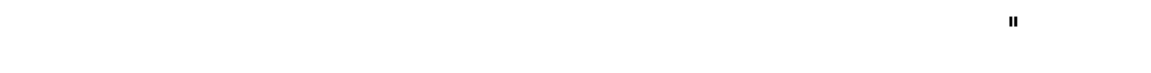

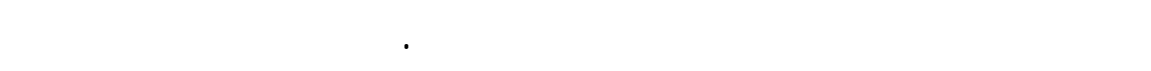

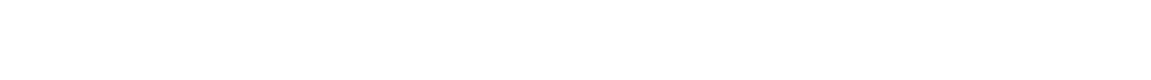

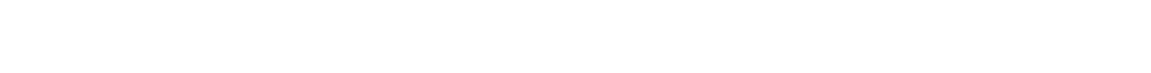
دون تعدد تلك المقررات أو تنتوعها.

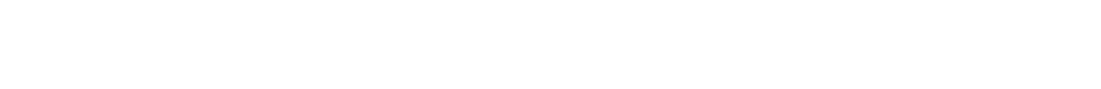

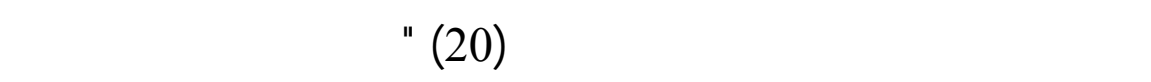

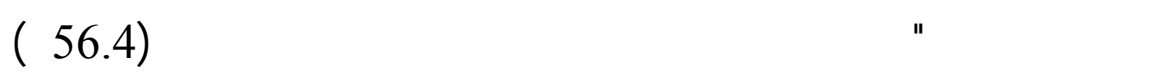

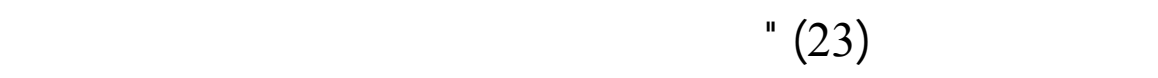

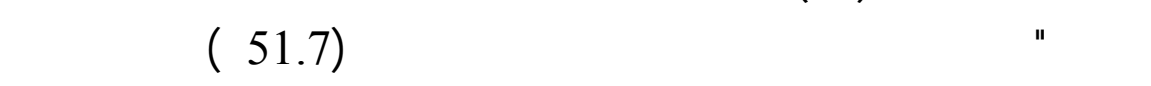

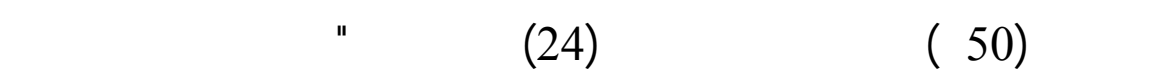

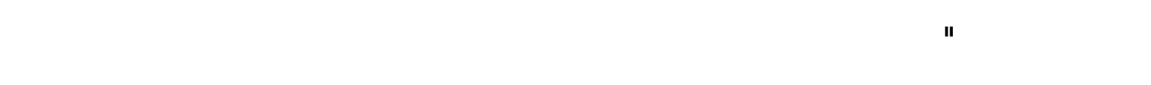

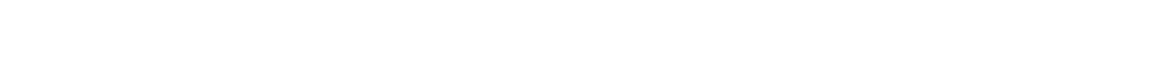

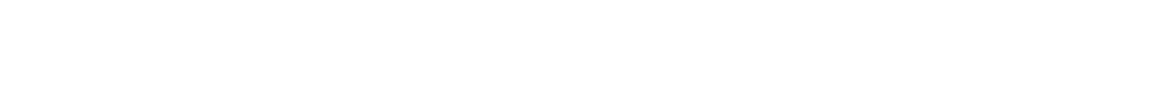

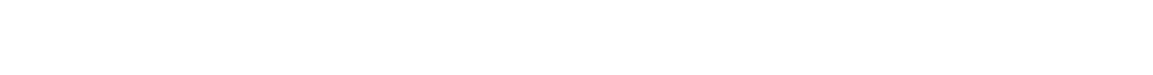

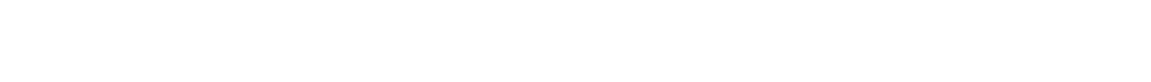

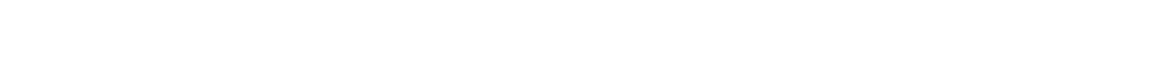

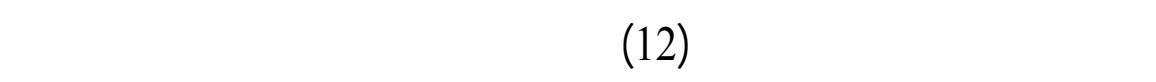




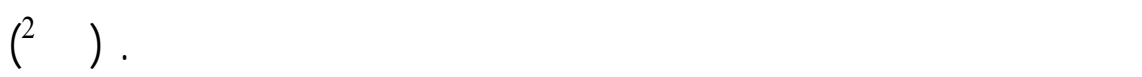

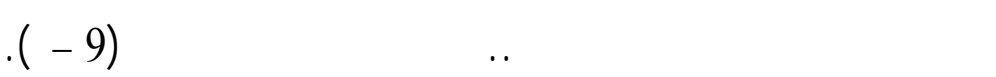

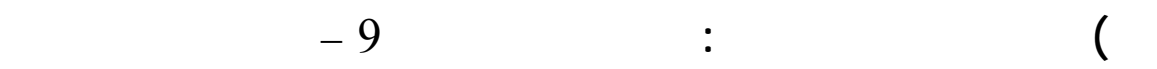

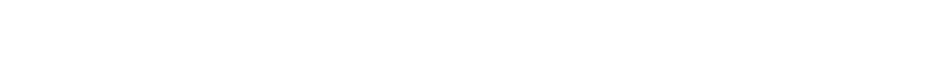

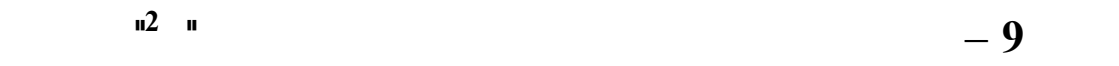
لالعينة الكلية علل بلى مشكلةفرعية من (هشكلات البهث العلية).

\begin{tabular}{|c|c|c|c|c|c|c|c|c|}
\hline \multirow[t]{3}{*}{ الدلالة } & \multirow[t]{3}{*}{ كا2 } & \multicolumn{6}{|c|}{ العينة الكلية (لن - 211) } & \multirow{3}{*}{ المؤشيرت } \\
\hline & & \multicolumn{2}{|c|}{ غيرموائ } & \multicolumn{2}{|c|}{ إلى حدما } & \multicolumn{2}{|c|}{ مواثق } & \\
\hline & & $\%$ & عدد & $\%$ & عدد & $\%$ & عدد & \\
\hline 0.0001 & 140.38 & 7.1 & 15 & 21.3 & 45 & 70.1 & 148 & 1 \\
\hline 0.0001 & 144.04 & 5.2 & 11 & 19.4 & 41 & 66.8 & 141 & 2 \\
\hline 0.0001 & 162.07 & 5.2 & 11 & 17.5 & 37 & 70.1 & 148 & 3 \\
\hline 0.0001 & 219.24 & 5.2 & 11 & 12.8 & 27 & 80.1 & 169 & 4 \\
\hline 0.0001 & 158.27 & 5.7 & 12 & 19.9 & 42 & 72- & 152 & 5 \\
\hline 0.0001 & 249.03 & 4.7 & 10 & 10.4 & 22 & 83.9 & 177 & 6 \\
\hline 0.0001 & 211.24 & 5.7 & 12 & 11.8 & 25 & 80.1 & 169 & 7 \\
\hline 0.0001 & 235.59 & 5.2 & 11 & 11.4 & 24 & 82.5 & 174 & 8 \\
\hline 0.0001 & 73.67 & 12.8 & 27 & 24.6 & 52 & 58.3 & 123 & 9 \\
\hline 0.0001 & 162.09 & 7.6 & 16 & 16.1 & 34 & 72- & 152 & 10 \\
\hline 0.0001 & 190.79 & 4.7 & 10 & 16.6 & 35 & 76.3 & 161 & 11 \\
\hline 0.0001 & 104.38 & 10- & 21 & 22.7 & 48 & 64- & 135 & 12 \\
\hline
\end{tabular}

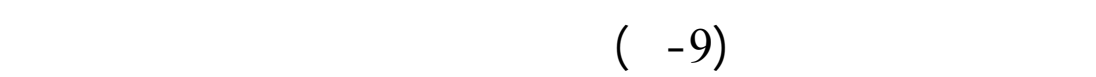

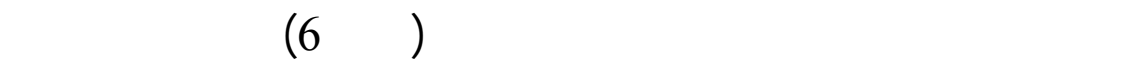

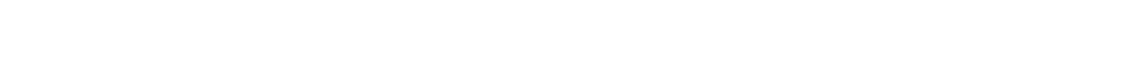
(83.9٪) يليها بند (5) مش كلة "ضض عف الإمكان لت الحالي ـة لمكتب ـة 


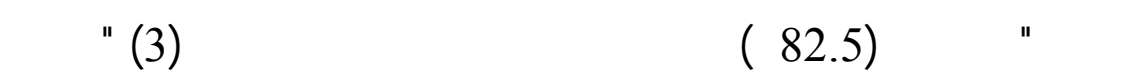

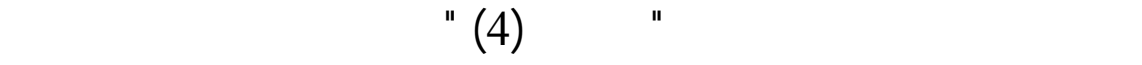

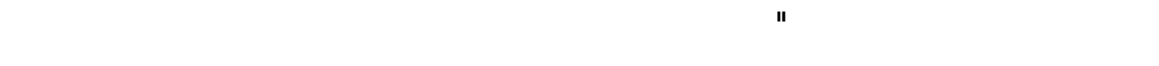

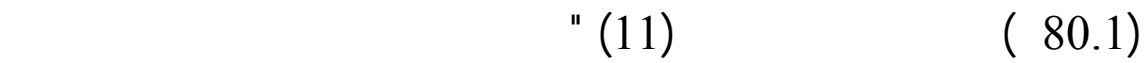

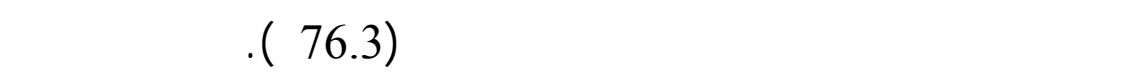

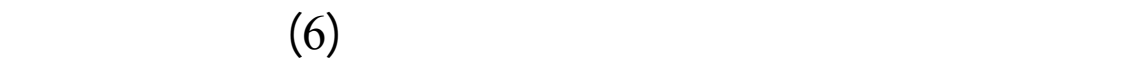

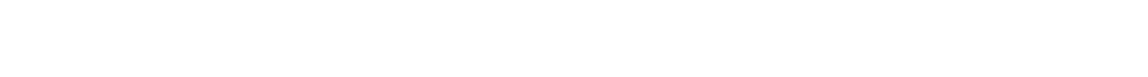

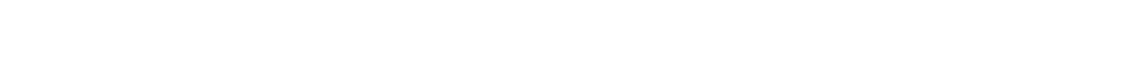

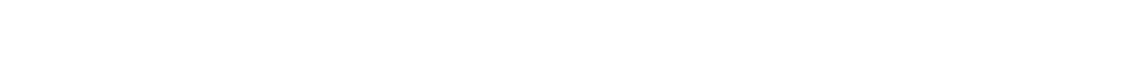

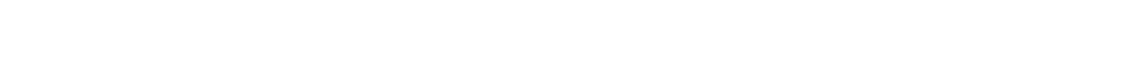

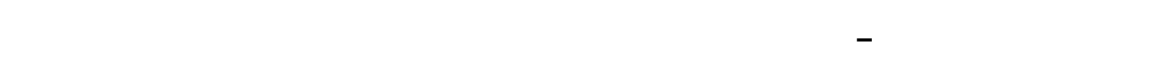

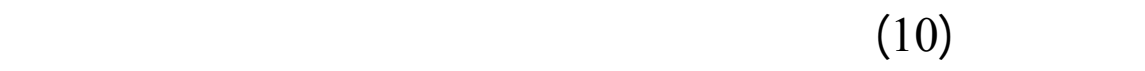

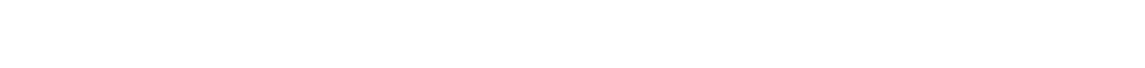

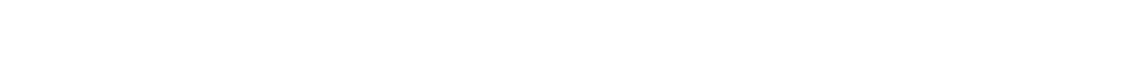

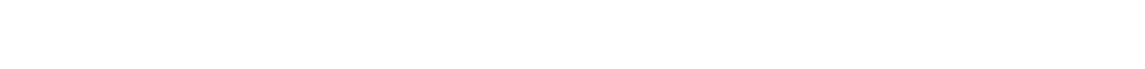
العلمية.

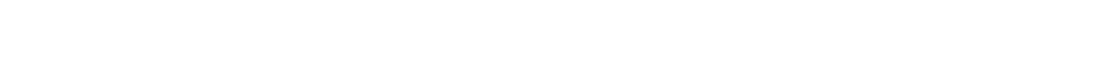

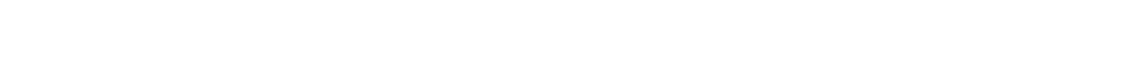

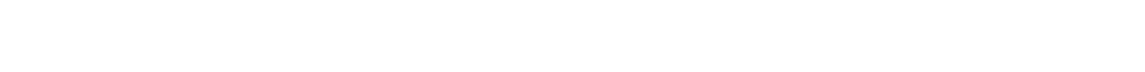

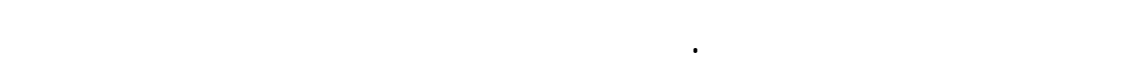

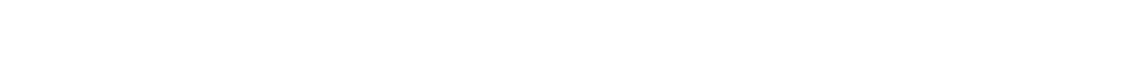

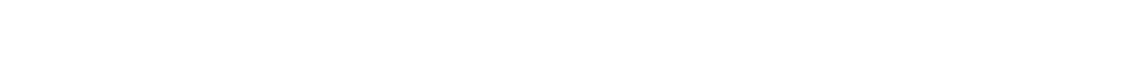
هيئة التدريس في مجل البحث العلهي. 


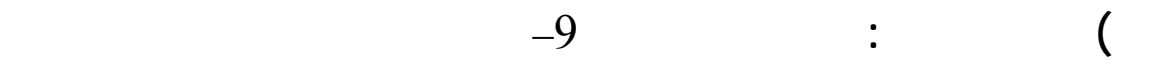
الموافقة على كل مشكلة من مشكلات النمو المهني.

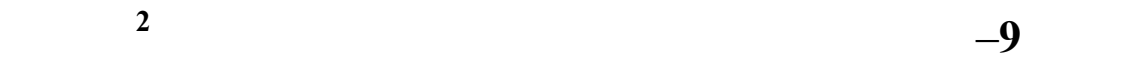
اللعينة الكلية عل لكل مشكلة فرعية من مشكلات (النو المهن).

\begin{tabular}{|c|c|c|c|c|c|c|c|c|}
\hline \multirow[t]{3}{*}{ الدلالة } & \multirow[t]{3}{*}{ كا2 } & \multicolumn{6}{|c|}{ العينة الكلية لن - 211) } & \multirow{3}{*}{ 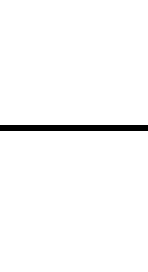 } \\
\hline & & \multicolumn{2}{|c|}{ غيرموائق } & \multicolumn{2}{|c|}{ إلل حدما } & \multicolumn{2}{|c|}{ موايق } & \\
\hline & & $\%$ & عدد & $\%$ & عدد & $\%$ & عدد & \\
\hline 0.01 & 8.46 & 24.2 & 51 & 40.3 & 85 & 33.2 & 70 & $\mathbf{1}$ \\
\hline 0.0001 & 32.38 & 15.6 & 33 & 36- & 76 & 46.9 & 99 & 2 \\
\hline 0.0001 & 78.24 & 10.9 & 23 & 27.5 & 58 & 59.2 & 125 & 3 \\
\hline 0.0001 & 114.33 & 8.5 & 18 & 24.2 & 51 & 66.4 & 140 & 4 \\
\hline 0.0001 & 140.82 & 6.6 & 14 & 20.9 & 44 & 69.2 & 146 & 5 \\
\hline 0.0001 & 164.09 & 6.2 & 13 & 19.4 & 41 & 73.9 & 156 & 6 \\
\hline 0.001 & 116.42 & 8.1 & 17 & 22.3 & 47 & 64.9 & 137 & 7 \\
\hline
\end{tabular}

يتضح من الج دول (9 -ج ـ ــ الخ اص بهث لحل النم ـو المهز ي

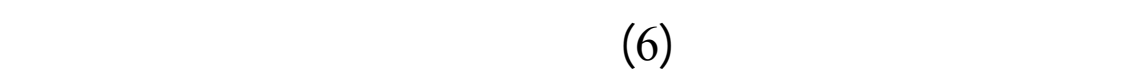

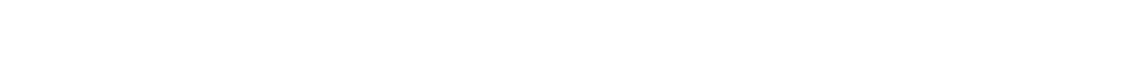

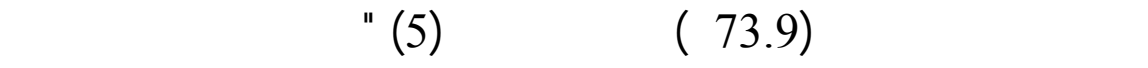

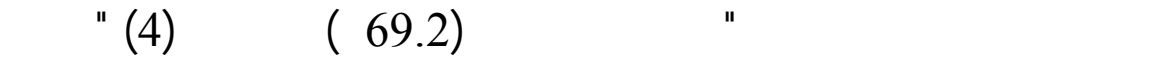

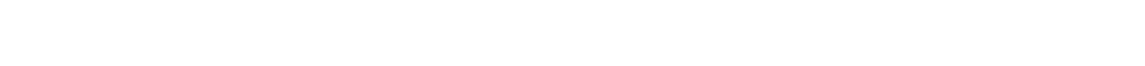

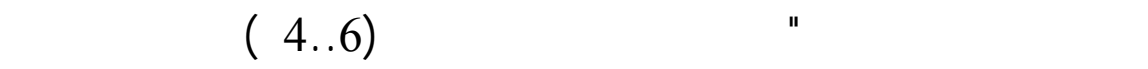


المرتبة الرابعة بند (7) 'قل ـة ء عدد الف ـرص المتلح ـة لعض -و هيئة

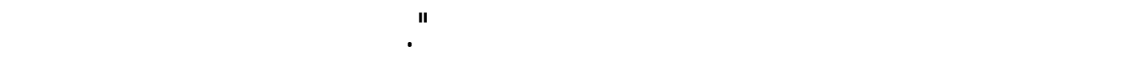

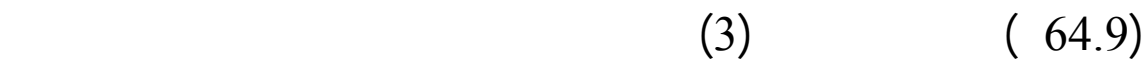

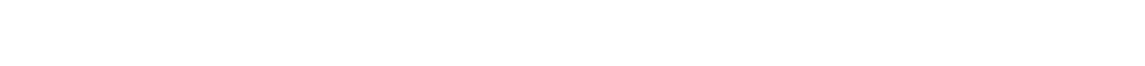

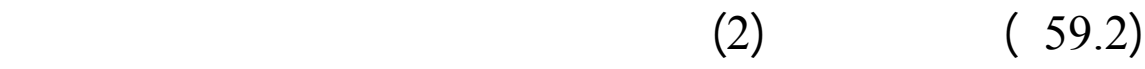

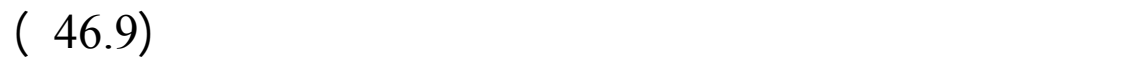

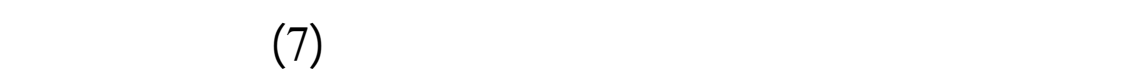

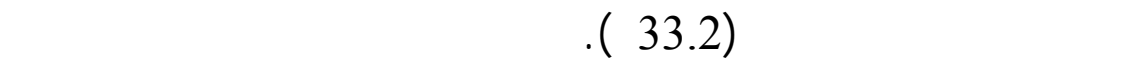

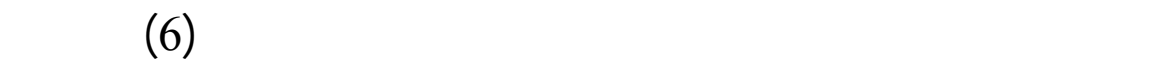

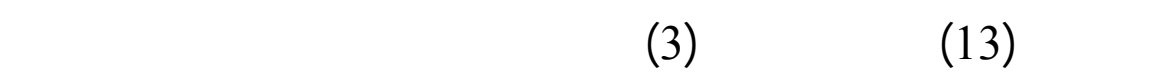

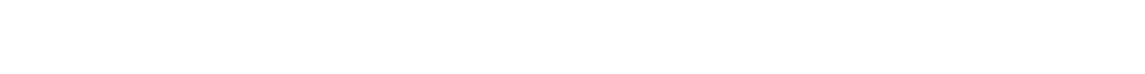

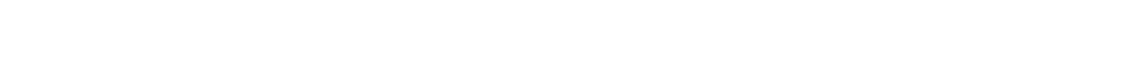

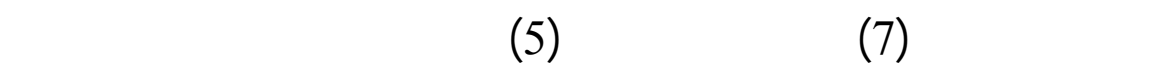

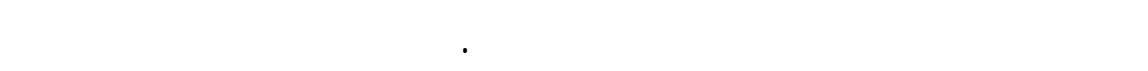

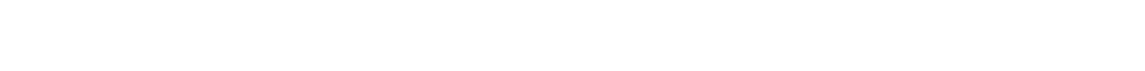

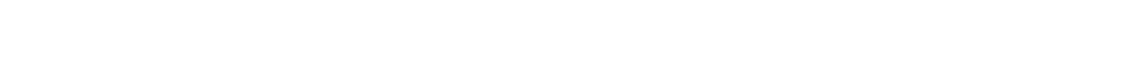

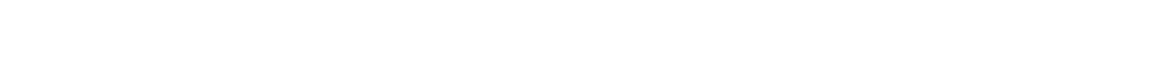

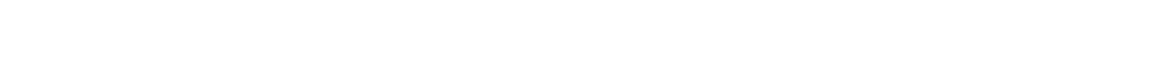

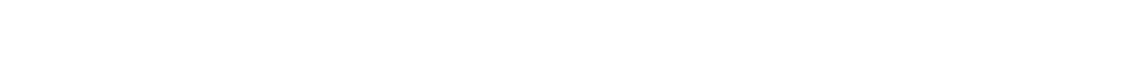

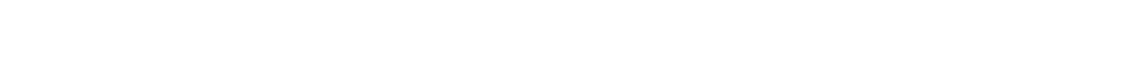

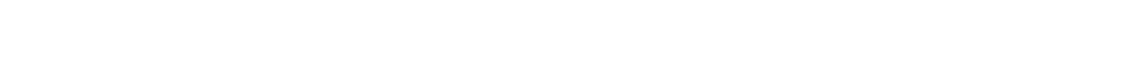
الدرلسة. 


\section{ثلنياً: المشال الإداربة والمالية:}

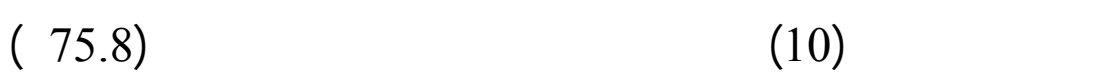

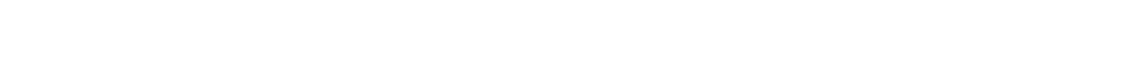

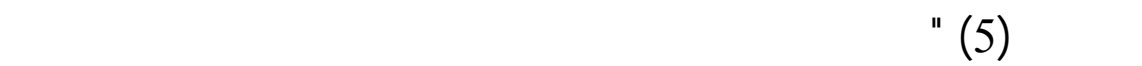

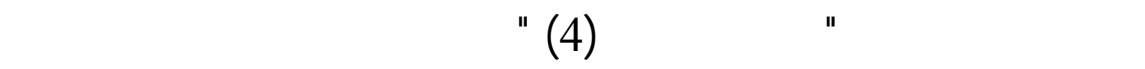

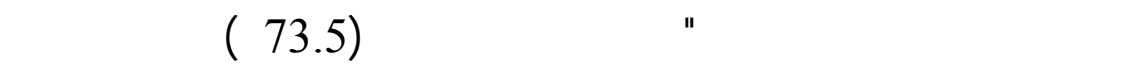

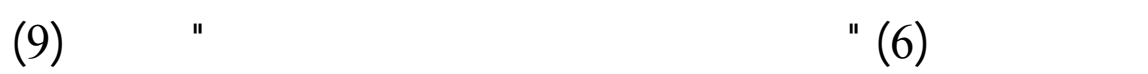

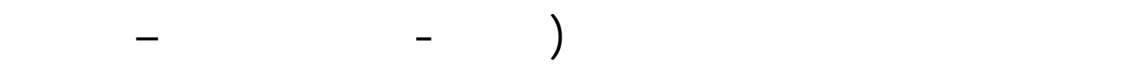

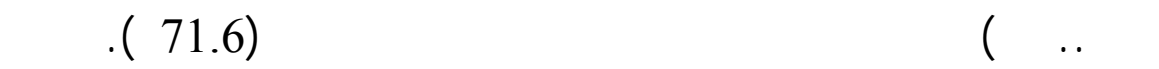

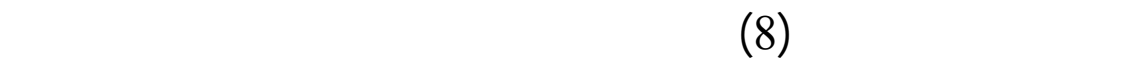

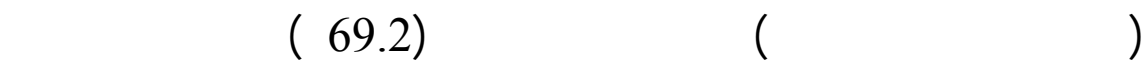

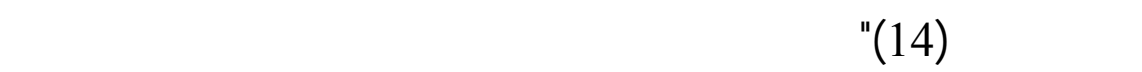

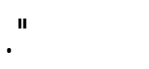

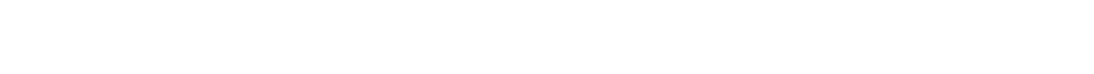
(9)، ومروان كمل (5)، اليونس كو (7)، وعنت ـر لطف مي (10)، الت مي التي

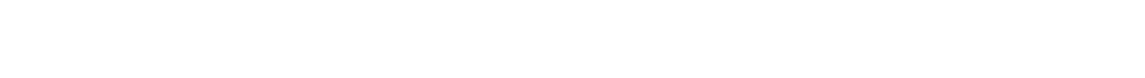

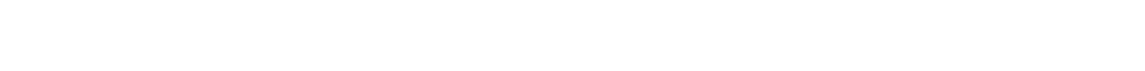

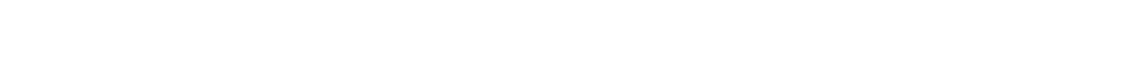

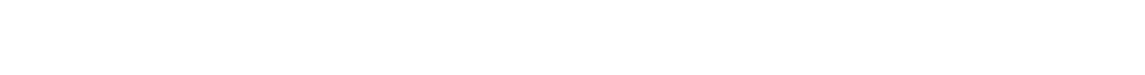
التدريس. 
جطر (10) يوضنح التكرارت والنسبة المئوبة لبدلل الإجلبة وكا2 ودلالتها لالعينة الكلية على كل مشكلةفرعية من (المشال الإداربة والمالية)

\begin{tabular}{|c|c|c|c|c|c|c|c|c|}
\hline \multirow[t]{3}{*}{ الدلالة } & \multirow[t]{3}{*}{ كا2 } & \multicolumn{6}{|c|}{ العينة الكلية لن - 211) } & \multirow{3}{*}{ المالمؤشرك } \\
\hline & & \multicolumn{2}{|c|}{ غيرموايق } & \multicolumn{2}{|c|}{ إلى حدما } & \multicolumn{2}{|c|}{ موائق } & \\
\hline & & $\%$ & عدد & $\%$ & عدد & $\%$ & عدد & \\
\hline 0.01 & 50.81 & 19- & 40 & 23.7 & 50 & 55.5 & 117 & 1 \\
\hline 0.001 & 26.29 & 20.4 & 43 & 29.4 & 62 & 48.3 & 102 & 2 \\
\hline 0.0001 & 45.11 & 17.1 & 36 & 28.9 & 61 & 54- & 114 & 3 \\
\hline 0.0001 & 172.03 & 6.6 & 14 & 16.1 & 34 & 73.5 & 155 & 4 \\
\hline 0.0001 & 186.42 & 5.2 & 11 & 16.6 & 35 & 75.8 & 160 & 5 \\
\hline 0.0001 & 150.73 & 5.7 & 12 & 21.8 & 46 & 71.6 & 151 & 6 \\
\hline 0.0001 & 34.2 & 14.7 & 31 & 36.5 & 77 & 46.4 & 98 & 7 \\
\hline 0.0001 & 130.20 & 8.1 & 17 & 22.3 & 47 & 69.2 & 146 & 8 \\
\hline 0.0001 & 149.78 & 6.2 & 13 & 21.3 & 45 & 71.6 & 151 & 9 \\
\hline 0.0001 & 77.40 & 11.8 & 25 & 27.5 & 58 & 60.2 & 127 & 10 \\
\hline 0.0001 & 66.70 & 10.9 & 23 & 31.3 & 66 & 56.4 & 119 & 11 \\
\hline 0.008 & 9.73 & 24.2 & 51 & 30.8 & 65 & 41.2 & 87 & 12 \\
\hline غير طالة & 3.56 & 33.2 & 70 & 27- & 57 & 37.4 & 79 & 13 \\
\hline 0.0001 & 133.04 & 14.2 & 30 & 12.3 & 26 & 67.8 & 143 & 14 \\
\hline 0.0001 & 92.97 & 9- & 19 & 26.1 & 55 & 61.1 & 129 & 15 \\
\hline
\end{tabular}


وبناءً على المشلكل للسابقة فإن عض -و هيئ ـة الت ـدربس بجلمع ـة

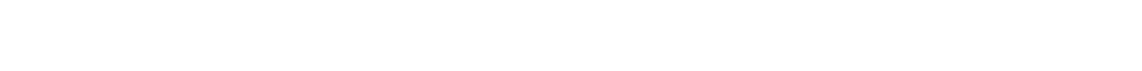

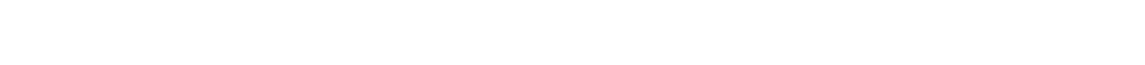

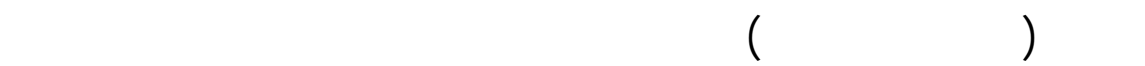

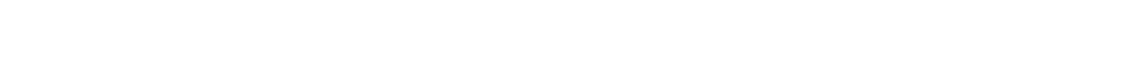

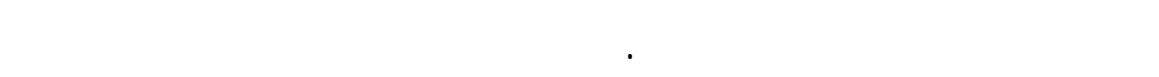

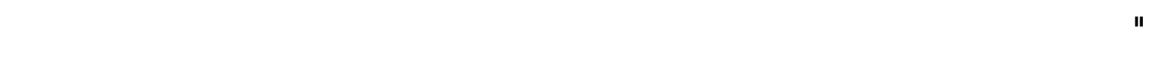

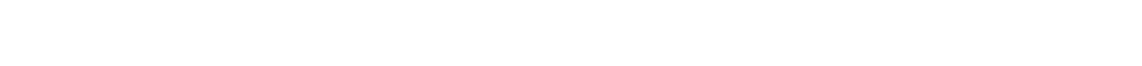
يوضح مدى معانة أعضاء هيئة التدريس م حن تل لك الجوان يب للس لـ لبية التي تعيق توفير الجو الفني والمناخ العلمي المنليب لهو.

شالثَا: المشال الجتماعية:

بالظر إلى الجدول (11) يتضح لن أعلى نسبة موافقة جاعت للبند (3) "ضعف رواطط الاتصل والتعاون بين الأقسلم العلمية بالجلمعة" والتي التئي بلغت نسبتها (54.5\%) وجاء في المرتبة الثانية بند (4) "ظهور الثللية وآثارها على العلاقت الاجتماعية ... الخ" بنسبة موافقة بلغت (47.4٪)

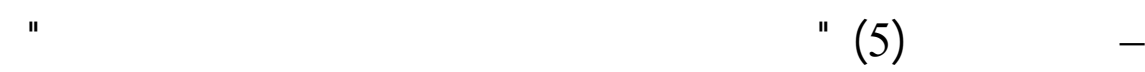
بنسبة بلغت (46.4\%) وجاء في الترتيب الرالع بند (8) "عدم الاهتملم بقوية العلاقة بين أعضاء هيئة التدريس"، الذي حقق نسبة موافقة بلغت (43.6\%) وجاء في الترتيب الخله بند (6) الخاص بمشكلة "الضغوط

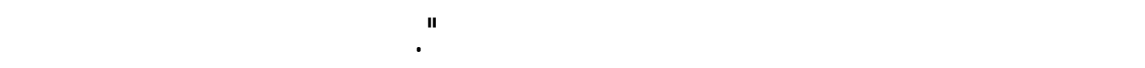

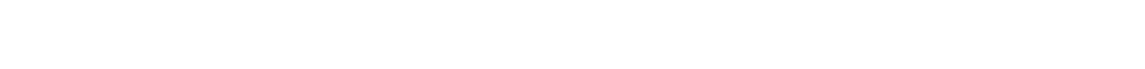

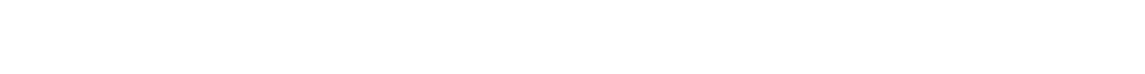
للشللية كمشكلة فضضي على الإرواط الاجتماعية بين الأقسه العلمية

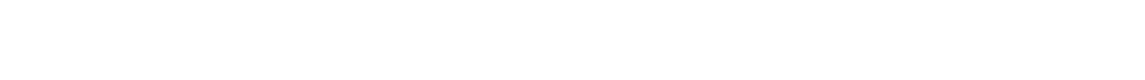


أعضاء هيئة التدربيس حيث التضح عام الاهتملم بإقلمة لنشطة لجتماعية بينهم كالرحلات العائلية أو تبال الزئ الزيارات. جرط (11) يوضنح التكرارات والنب المئوبة لبدالل الإجلبة وكا2 ودلالنها

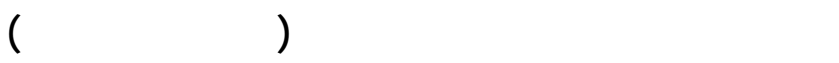

\begin{tabular}{|c|c|c|c|c|c|c|c|c|}
\hline \multirow[t]{3}{*}{ الدلاة } & \multirow[t]{3}{*}{${ }^{2} \mathbf{K}$} & \multicolumn{6}{|c|}{ العينة الكلية (ن - 211) } & \multirow{3}{*}{ المالمؤشرلة } \\
\hline & & \multicolumn{2}{|c|}{ غيرموالق } & \multicolumn{2}{|c|}{ إل حما } & \multicolumn{2}{|c|}{ موذق } & \\
\hline & & $\%$ & عدد & $\%$ & عدد & $\%$ & عدد & \\
\hline 0.01 & 18.85 & 26.1 & 55 & 45- & 95 & 23.2 & 49 & 1 \\
\hline 0.0001 & 45.33 & 10.4 & 22 & 42.7 & 90 & 42.5 & 89 & 2 \\
\hline 0.0001 & 76.69 & 6.6 & 14 & 34.1 & 72 & 54.5 & 115 & 3 \\
\hline 0.0001 & 30.64 & 17.5 & 37 & 28.9 & 61 & 47.4 & 100 & 4 \\
\hline 0.0001 & 30.51 & 18.5 & 39 & 24.6 & 52 & 46.4 & 98 & 5 \\
\hline 0.0001 & 20.41 & 19.4 & 41 & 27.5 & 58 & 43.1 & 91 & 6 \\
\hline 0.0001 & 4.30 & 28.9 & 61 & 25.1 & 53 & 36- & 76 & 7 \\
\hline 0.0001 & 25.22 & 16.6 & 35 & 34.1 & 72 & 43.6 & 92 & 8 \\
\hline 0.0001 & 11.71 & 19- & 40 & 34.6 & 73 & 34.6 & 73 & 9 \\
\hline 0.0001 & 43.31 & 52.1 & 110 & 22.3 & 47 & 19.9 & 42 & 10 \\
\hline 0.0001 & 4.33 & 25.6 & 54 & 37- & 78 & 30.8 & 65 & 11 \\
\hline 0.008 & 20.90 & 21.8 & 46 & 44.5 & 94 & 25.1 & 53 & 12 \\
\hline
\end{tabular}

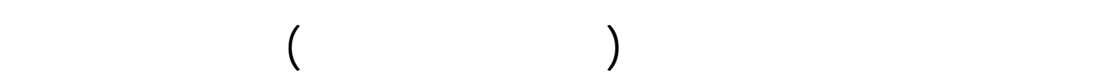

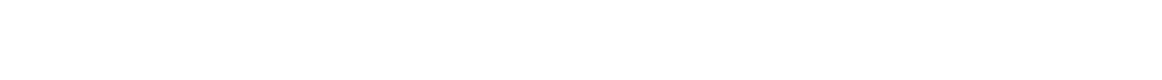

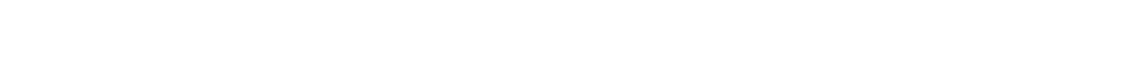
لمتعراضضها على النحو الآتي: 


\section{أولاً: المشال العامية:}

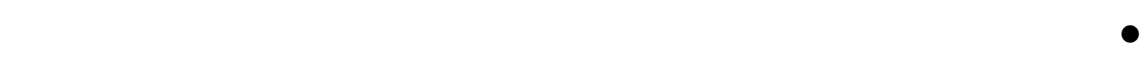

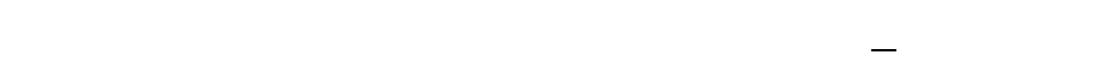

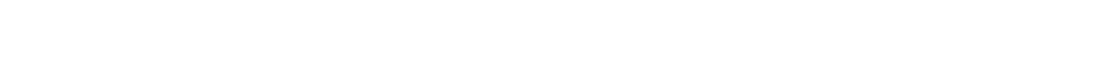

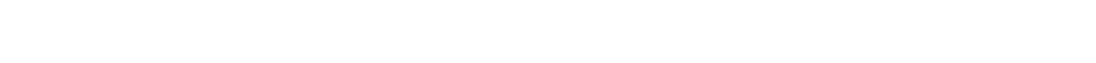
التكيف والإضاعة والظافة.

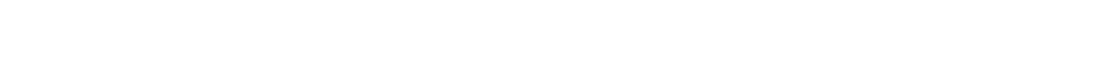

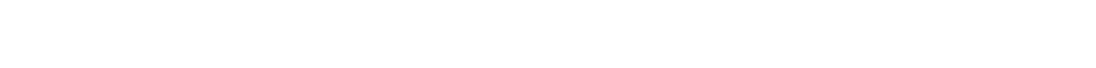
الدائم عن المحاضرات.

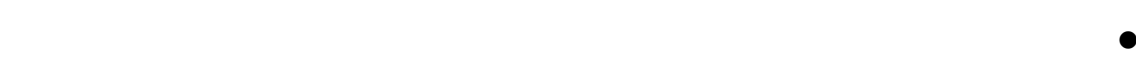

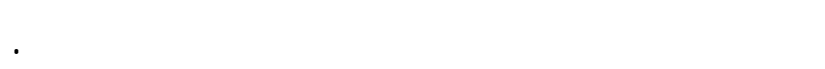

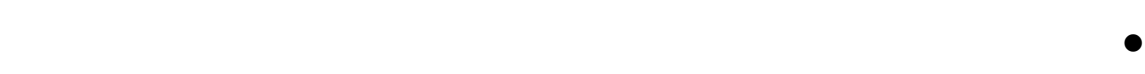

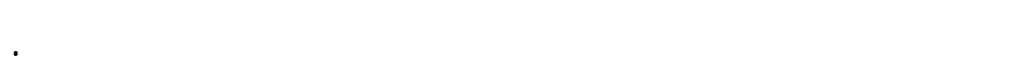

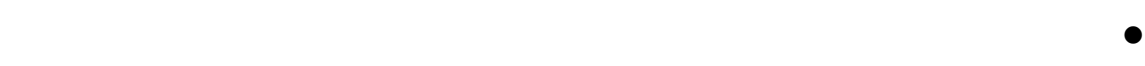
الأبحلث التي يقنم بها أعضاء هيئة التدربيس. • ع عم توافر قاعلت منلسبة لاجتماعلت الأفسلم العلمية. • زيادة أعداد الطلاب في غاعلب غالبية المجموعلت الدرلسية. • عدم إعاء عضو هيئة التدربيس الحرية الكافية في المشاركة بإع إعداد المادية

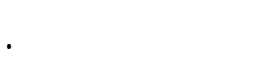

\section{شانياً: المشال الإدارية:}

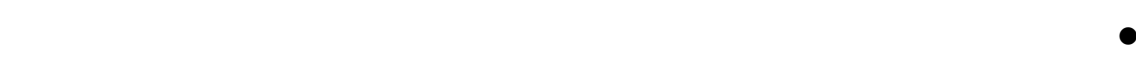

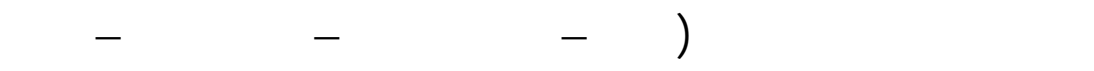
رئيس قمم ). • الفقار الأفسلم العلمية لذظيفة مساعد بلمث علمي. 
• توظيف غير المؤهلين في الوظافف الإدارية المختلفة بالجلمعة.

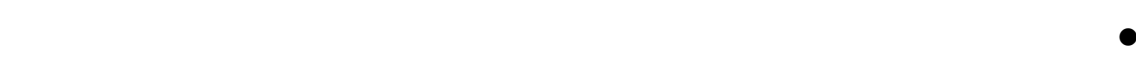
لأعضاء هيئة التدريس. • فقدان الخملت اللازمة لأعضاء هيئة التدربي.

ثالثاً: المشالى الجتماعي ـ ـ ـة: • ضعف روابط الاتصل والتعاون بين أعضاء هيئة التدريس في الأقسلم العلمية المختلفة. • توتر العلاقت بين بعض المخلة أعضاء هيئة التدريس ف مي القس م العلم ي الولحد وعدم لحترام العلاقلت المهنية.

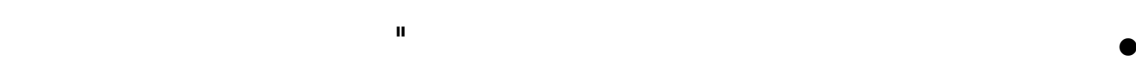

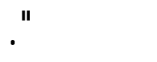
يتضح من العرض السابق لنتائج الدرلسة أن أهم المشلكل العلمية التي

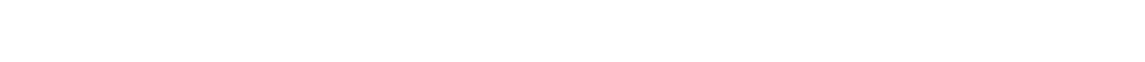

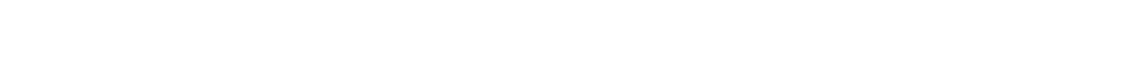

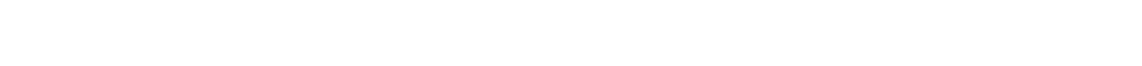

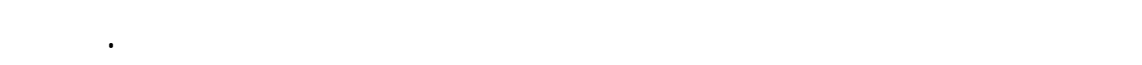

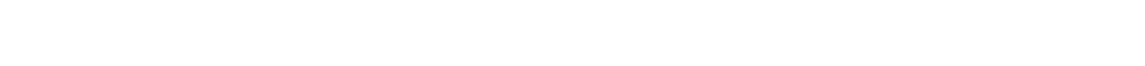

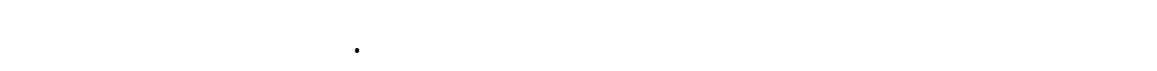

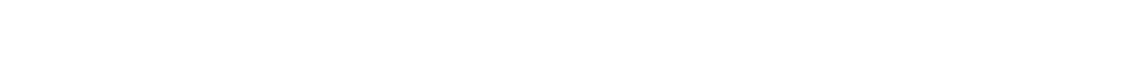

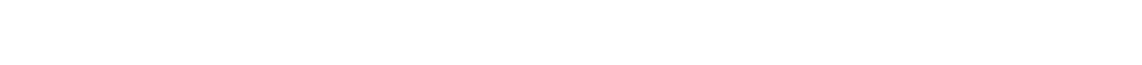
علمية مختصة وعدم تخخصيص ميزالنية كلفية للبهث العلمي. 


\section{التوصيلت:}

في ضوء ما أسفرت عنه الدرلسة من نتائج، ولمعالجة المشلكل الت مي ظهرت، تقترح البلحثة ما يأتي: البفرث النولي

\section{أولاً: فيما ينهاق بالهشال العامية:}

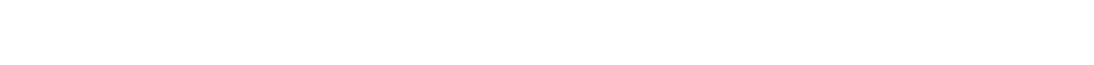
مع مواصفلت البيئية التعليمية التربوية ويدقق فاعلية عملية التدريب، من

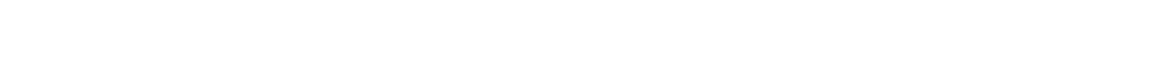

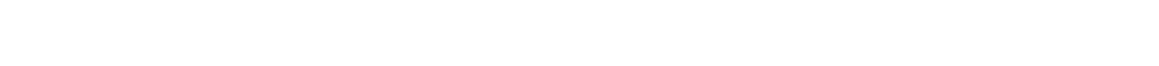

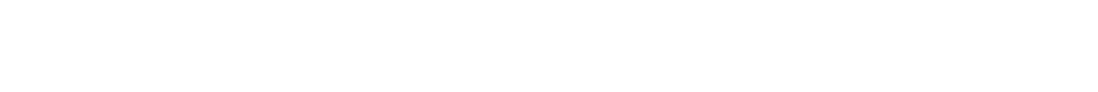

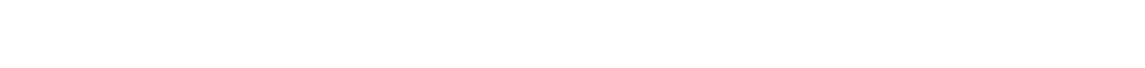
العلمي وتحفيزهم بشكل مبلثر للعملية التعليمية.

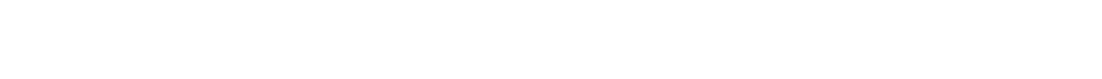

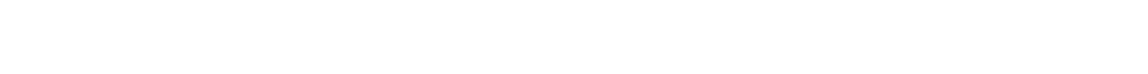

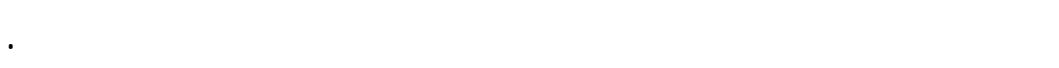

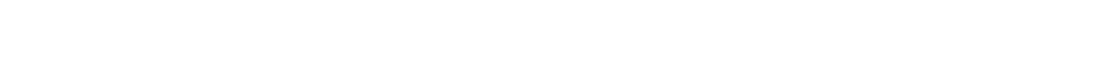

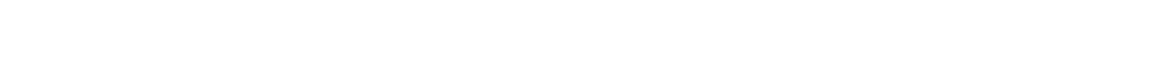

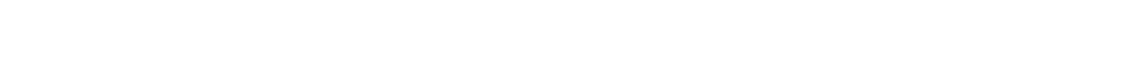

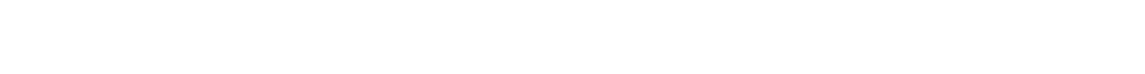

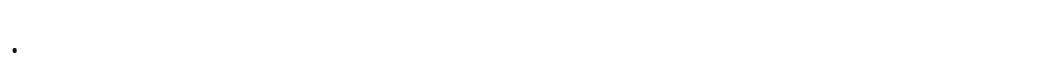

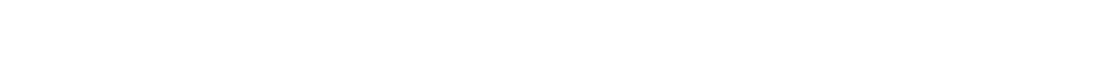

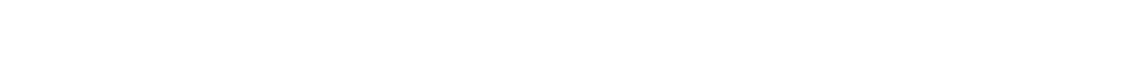

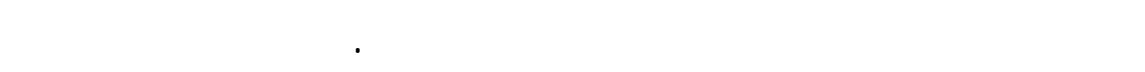


من إمكانت ماية وبشرية مع إلالة الدواه الرسمي لها.

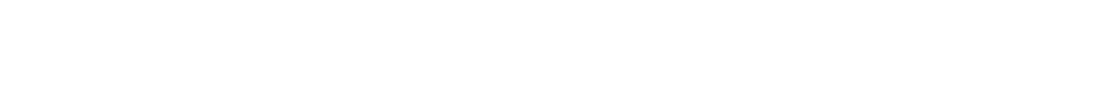

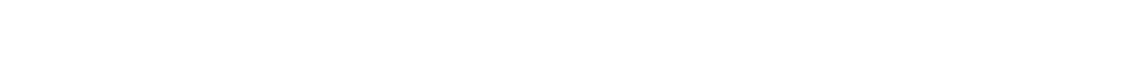

يققدون لها.

ثانياً:فيما يتهاق بالمشالى الإداربة والمالية: 1) توفير وظفة مساعد بلمث في جمبع الأقسل العلمية بالكلية، يكون عونا لعضو هيئة التدريس في القي لم

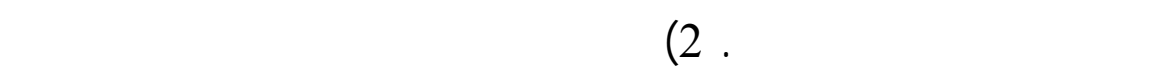

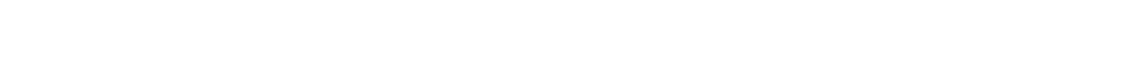

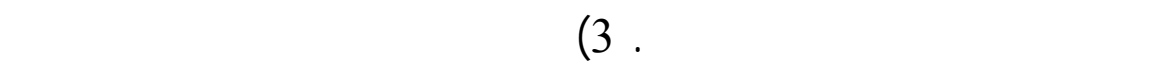

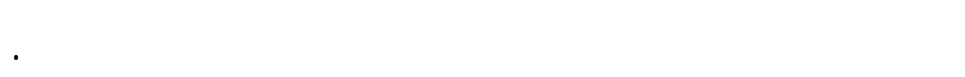




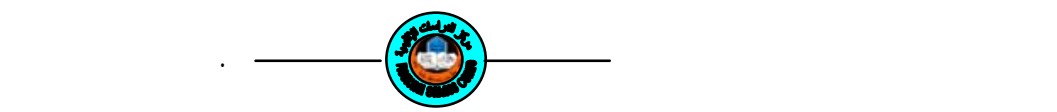

PROBLEMS FACING MEMBER STAFF AT AL-AGHWATT

UNIVERSITY (ALGERIA) AND AFFECTING HIS

PERFORMANCE LEVEL

\author{
Dr. Ma'araj Abdul-Qadir Houari \\ Deputy Dean For Higher Education, Al-Aghwatt Uniwersity, Al-geria
}

\begin{abstract}
This study aimed to identify the most important problems and obstacles faced by the faculty member of the University of Blida, and adversely affect the level of his performance career. It also aimed to identify the most obvious problems in the areas of scientific, administrative, financial and social. The researchers prepared a questionnaire consisted of (71) each word reflects on the nature of the problem may suffer from a member of the faculty in the areas of Macedonia. Tool has been applied to members of the University Staff, has been found from the analysis of the results and their interpretation that there are many problems it faces faculty member adversely affect the level of functional performance in the light of these findings by researchers with a series of recommendations that would develop appropriate solutions to address those Constraints against a member of the faculty.
\end{abstract}

Key words: faculty, functionality, higher education, the conduct of higher education. 
مراجع الدرلسة وهولهشها

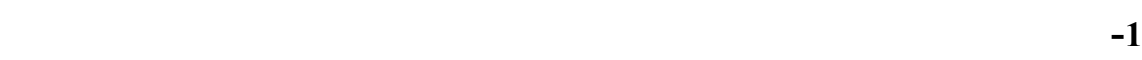
العربية التربية والقفة والعلون. التحلد الجامعت العربية، ت ـوس 1987 - ص

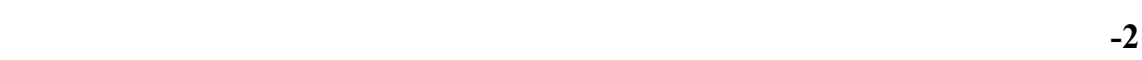

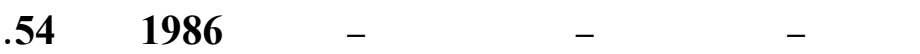

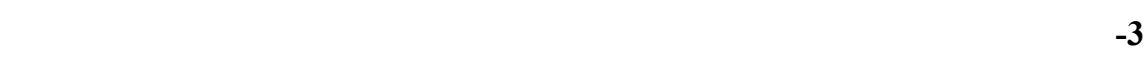

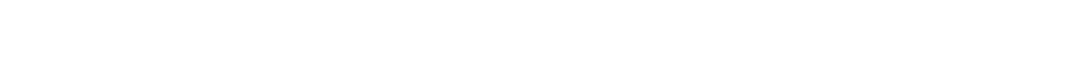

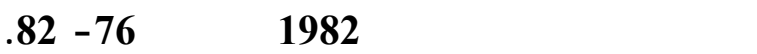

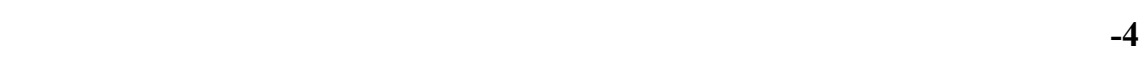

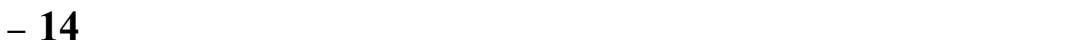

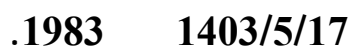

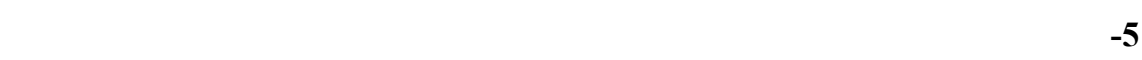

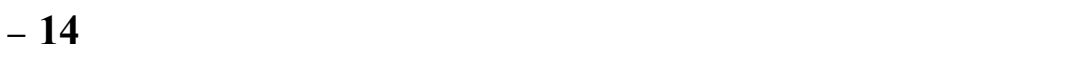

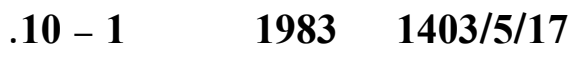

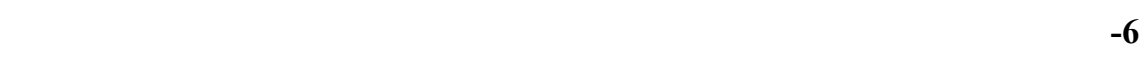

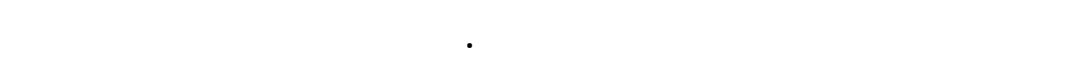

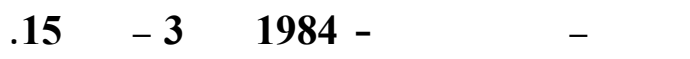

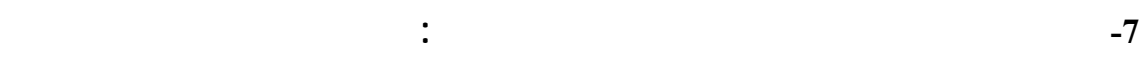

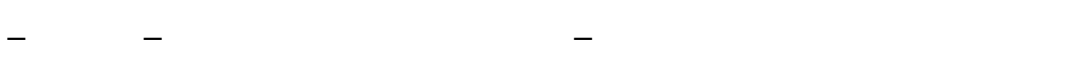

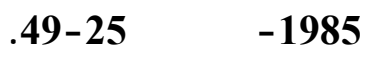

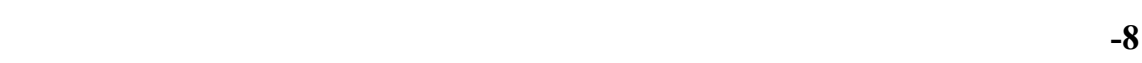

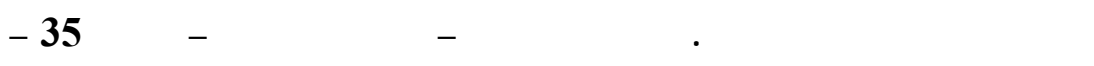

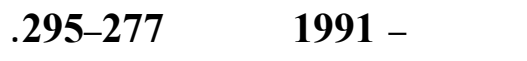

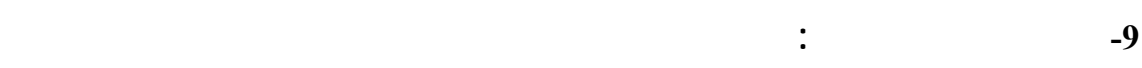

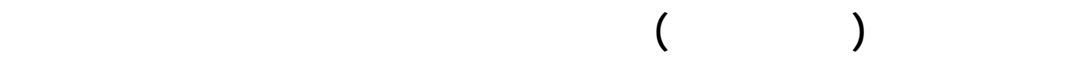
جامعة لُ ولم القرى -مكة المكرمة 1411هـ ــ 1991. 


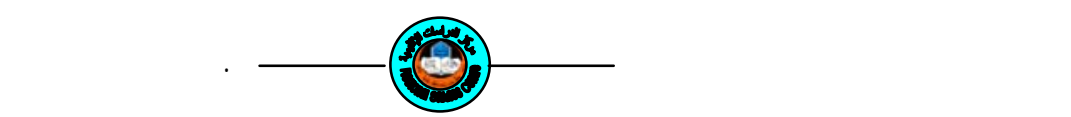

10- عنتر للافي محمد، المشال التي تولجه أعضاء هيئة التربس بـ بهض كلي لت

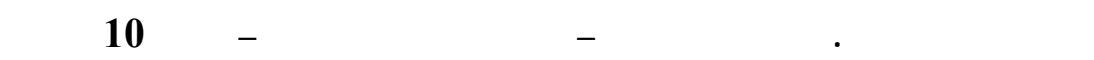

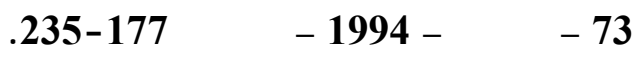

11- Rose Mary, Cligg, University of Southern California Faculty theirviews of the University, ERIC Document No ED 096917.1977.

12- Lindaa, S. Moxlcy, Job Satisfaction of Faculty Teaching: Higher examination of Herzerg Porter Need Satisfaction Research. ERIC Document No. ED 139343, June, 1977.

13- Jess, F. Seegnileer, Job Satisfaction of Faculty and Staff at The College of Eastern Utah , ERIC Document No. E D.1983. P.p. 217- 220.

14- Pedrot. Orata, The Problem professor of Education. The Journal of Higher Education. 1999 P.P. 589-598.

15- Suzanne, Young \& Dale Shaw, Profiles of Effective Collage and University Teachers. The Journal of Higher Education. 1999. PP671 684.

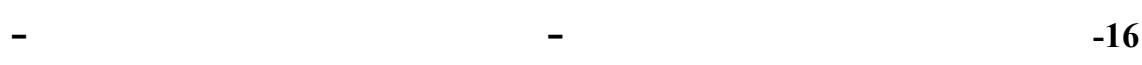

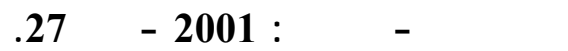

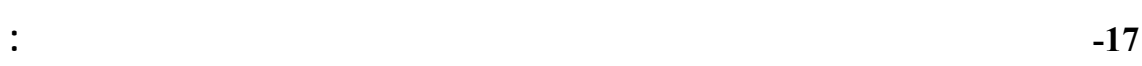

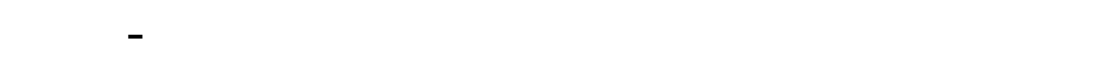

2000-ص ص ص 2116 -138 